\title{
Allogeneic guinea pig mesenchymal stem cells ameliorate neurological changes in experimental colitis
}

\author{
Rhian Stavely ${ }^{1 \dagger}$, Ainsley M. Robinson ${ }^{1 \dagger}$, Sarah Miller ${ }^{1}$, Richard Boyd ${ }^{2}$, Samy Sakkal ${ }^{1}$ and Kulmira Nurgali ${ }^{1 *}$
}

\begin{abstract}
Background: The use of mesenchymal stem cells (MSCs) to treat inflammatory bowel disease (IBD) is of great interest because of their immunomodulatory properties. Damage to the enteric nervous system (ENS) is implicated in IBD pathophysiology and disease progression. The most commonly used model to study inflammation-induced changes to the ENS is 2,4,6-trinitrobenzene-sulfonate acid (TNBS)-induced colitis in guinea pigs; however, no studies using guinea pig MSCs in colitis have been performed. This study aims to isolate and characterise guinea pig MSCS and then test their therapeutic potential for the treatment of enteric neuropathy associated with intestinal inflammation.

Methods: MSCs from guinea pig bone marrow and adipose tissue were isolated and characterised in vitro. In in vivo experiments, guinea pigs received either TNBS for the induction of colitis or sham treatment by enema. MSCs were administered at a dose of $1 \times 10^{6}$ cells via enema $3 \mathrm{~h}$ after the induction of colitis. Colon tissues were collected 24 and $72 \mathrm{~h}$ after TNBS administration to assess the level of inflammation and damage to the ENS. The secretion of transforming growth factor- $\beta 1$ (TGF- $\beta 1$ ) was analysed in MSC conditioned medium by flow cytometry.

Results: Cells isolated from both sources were adherent to plastic, multipotent and expressed some human MSC surface markers. In vitro characterisation revealed distinct differences in growth kinetics, clonogenicity and cell morphology between MSC types. In an in vivo model of TNBS-induced colitis, guinea pig bone marrow MSCs were comparatively more efficacious than adipose tissue MSCs in attenuating weight loss, colonic tissue damage and leukocyte infiltration into the mucosa and myenteric plexus. MSCs from both sources were equally neuroprotective in the amelioration of enteric neuronal loss and changes to the neurochemical coding of neuronal subpopulations. MSCs from both sources secreted TGF- $\beta 1$ which exerted neuroprotective effects in vitro.
\end{abstract}

Conclusions: This study is the first evaluating the functional capacity of guinea pig bone marrow and adipose tissue-derived MSCs and providing evidence of their neuroprotective value in an animal model of colitis. In vitro characteristics of MSCs cannot be extrapolated to their therapeutic efficacy. TGF- $\beta 1$ released by both types of MSCs might have contributed to the attenuation of enteric neuropathy associated with colitis.

Keywords: Enteric neuropathy, Mesenchymal stem cells, Multipotent stromal cells, Colitis, Neuroprotection, Guinea pig, Bone marrow, Adipose tissue, Allogeneic, TGF- $\beta$

\footnotetext{
* Correspondence: kulmira.nurgali@vu.edu.au

${ }^{\dagger}$ Equal contributors

${ }^{1}$ Centre for Chronic Disease, College of Health and Biomedicine, Western Centre for Health, Research and Education, Sunshine Hospital, 176 Furlong road, Melbourne 3021Victoria, Australia

Full list of author information is available at the end of the article
} 


\section{Background}

Inflammatory bowel disease (IBD), comprising ulcerative colitis and Crohn's disease, is a chronic debilitating disorder currently increasing in incidence and prevalence [1]. Patients experience severe manifestations, including bloody stool, persistent diarrhoea or constipation (or both), abdominal pain, ulcerations, fistulae, structuring and perianal fissures [2]. Current treatment options include anti-inflammatory drugs (aminosalicylates), corticosteroids, immunomodulators (thiopurines, methotrexate and cyclosporine) and biological agents (anti-tumour necrosis factor-alpha); these treatments either are toxic in the long term or frequently fail to induce and maintain remission [3]. Patients unresponsive to therapy require removal of inflamed bowel segments; incidentally, almost $30 \%$ of patients with Crohn's disease will undergo their first bowel resection surgery within 7 years of diagnosis and subsequently require repeated surgeries [4]. Therefore, investigations into alternative therapies for IBD are essential. Recently, there has been interest in the use of probiotics to treat IBD (e.g., Mutaflor) with positive results achieved in some clinical trials [5]. Using live cells to modify the inflammatory response, as opposed to conventional drugs, remains an intriguing prospect.

In the past decade, mesenchymal stem cells (MSCs), also known as multipotent stromal cells, have emerged as a clinically viable therapy for many diseases, including IBD [6-8]. MSCs are defined by their differentiation capacity, adherence to plastic in standard culture and expression of specific surface markers [9]. MSCs are easily isolated from adult tissue sources, including adipose tissue and bone marrow; they are highly proliferative and fibroblast-like in appearance and form monolayer colonies in culture [10-13]. Furthermore, MSCs can be successfully transplanted between individuals and across species as they have been shown to be immune-evasive $[14,15]$. The presence of chemokine receptors on MSCs facilitates their migration toward inflammatory sites [16]. Once engrafted, MSCs suppress inflammation by immunomodulation via secretion of anti-inflammatory mediators [17]. MSCs can also exert regenerative effects through the secretion of pro-angiogenic and trophic factors which promote endogenous mechanisms of repair [18-20]. These properties make MSCs an attractive therapeutic option for IBD and have been widely studied in experimental colitis models and more recently in clinical trials for the treatment of Crohn's disease in which autologous (host-donor, the same individual) and allogeneic (host-donor, the same species) MSC transplants have been performed [21-23]. MSCs have also been shown to be neuroprotective in clinical trials and in a variety of disease models, including multiple sclerosis, brain and spinal cord injury, stroke, peripheral nerve injury, amyotrophic lateral sclerosis and neurodegenerative diseases [24-35]. These studies provide the foundation for investigating the potential efficacy of MSC therapy for the treatment of enteric neuropathy associated with intestinal inflammation.

Damage to the enteric nervous system (ENS) correlates with persistent intestinal inflammation and gut dysfunction and may provide an avenue for intervention in the treatment of IBD [36-39]. The ENS functions via a network of neurons and glial cells throughout the length of the gastrointestinal tract. Neuronal bodies and glial cells reside within the ganglia comprising two major plexuses: submucosal and myenteric. Neurons of the submucosal plexus primarily regulate intestinal secretion and vasodilation, whereas neurons of the myenteric plexus coordinate muscular contractions [40]. Within the ganglia, individual neuronal subpopulations have specific functions and are classified by morphology, electrophysiological properties and their immunoreactivity to neurochemical markers associated with the production of different neurotransmitters. In the myenteric plexus, the two major subpopulations of muscle motor neurons and interneurons are cholinergic and nitrergic. These neurons are identified by the expression of choline acetyltransferase (ChAT) and neuronal nitric oxide synthase (nNOS), indicating the synthesis of acetylcholine and nitric oxide, respectively.

Intestinal inflammation is associated with neuronal death and axonal damage [41-44]. Additionally, variations to the neurochemical coding of enteric neurons have been reported in experimental colitis models and human IBD biopsies; these changes are not restricted to sites of active inflammation [42, 45-48]. Specifically, changes to cholinergic and nitrergic neuronal subpopulations have been reported to be implicated in intestinal dysmotility [49]. Leukocyte infiltration to the enteric plexuses is predictive of postoperative disease reoccurrence in patients with Crohn's disease [50-52]. These observations suggest that neurological changes perpetuate inflammatory relapse and thus the ENS is a viable target for therapy.

Guinea pigs are the most common species used to study the functional and morphological properties of the ENS. The current knowledge of the neurochemical coding, morphological types and functional classification of enteric neurons was elucidated in guinea pigs $[40,53]$. Since the ENS is embedded within the gastrointestinal wall, clean dissection and isolation of enteric ganglia are the main hurdles to study the ENS; these can be more readily achieved in tissues from guinea pigs compared with other animals. Electrophysiological, biophysical and molecular studies of different functional types of enteric neurons and their ion channels have been performed predominantly in guinea pigs [53-55].

Experimental models in guinea pigs have significantly contributed to the understanding of the pathophysiology 
for many human diseases, including cardiovascular, pulmonary, infectious, auditory and gestational disorders [56-61]. The 2,4,6-trinitrobenzene-sulfonic acid (TNBS)induced model of colitis in guinea pigs has provided valuable data on functional, morphological and immunohistochemical changes of the ENS associated with intestinal inflammation [42, 43, 62-65]. The efficacy of xenogeneic (host-donor, different species) human MSC treatments has been tested in guinea pig models of osteoarthritis and radiation damage to the nasal mucosa $[66,67]$. Our recent study in the guinea pig model of TNBS-induced colitis demonstrated the therapeutic potential of human MSCs for the treatment of inflammationinduced enteric neuropathy [68]. These studies may have benefited from the use of allogeneic MSCs to better replicate transplantation in a clinical setting. Given the value of guinea pig models in biomedical research, an investigation establishing the functional efficacy of allogeneic guinea pig MSCs is warranted. In this study, we present data on the isolation, in vitro characterisation and in vivo application of allogeneic MSCs for the treatment of enteric neuropathy associated with experimental colitis in guinea pigs.

\section{Methods}

\section{Animals}

Male and female Hartley guinea pigs weighing 140-280 g were received from the South Australian Health and Medical Research Institute. All guinea pigs were housed in a temperature-controlled environment with $12-\mathrm{h}$ day/night cycles and had ad libitum access to food and water. All procedures were performed under approval of the Victoria University Animal Experimentation Ethics Committee and conducted in accordance with the Australian National Health and Medical Research Council Code of Practice for the Care and Use of Animals for Scientific Purposes.

\section{Isolation of MSCs from guinea pig adipose tissue}

Visceral adipose tissue was obtained from guinea pigs. Tissues were collected in minimum essential medium with alpha modifications ( $\alpha$-MEM) (Gibco, part of Life Technologies, Melbourne, Australia) supplemented with $100 \mathrm{U} / \mathrm{ml}$ penicillin/streptomycin (Gibco). Samples were cut into $10-\mathrm{mm}$ strips and incubated at $37{ }^{\circ} \mathrm{C}$ for $30 \mathrm{~min}$ in $5 \mathrm{ml}$ of $\alpha$-MEM with $100 \mathrm{U} / \mathrm{ml}$ penicillin/ streptomycin and $25 \mu \mathrm{g} / \mathrm{ml}$ liberase ${ }^{\mathrm{Tx}}$ (Roche, Basel, Switzerland). The adipose tissue was placed in C-tubes (Miltenyi Biotec, Bergisch Gladbach, Germany) and homogenised with a GentleMACS automated dissociator (Miltenyi Biotec) prior to and after an additional incubation step for $30 \mathrm{~min}$ at $37^{\circ} \mathrm{C}$. Enzymatic digestion was then inhibited by placing tubes on ice and diluting samples with $\alpha$-MEM supplemented with penicillin/ streptomycin. The connective tissue was removed via filtration at $40 \mu \mathrm{m}$. Samples were centrifuged at $500 \mathrm{~g}$ for 5 min, supernatant was removed and the pellet of cells was resuspended in $1 \mathrm{ml}$ of expansion medium ( $\alpha$-MEM supplemented with $100 \mathrm{U} / \mathrm{ml}$ penicillin/streptomycin, $1 \%$ glutaMAX (Gibco) and $16.5 \%$ foetal bovine serum (mesenchymal stem cell-qualified; Gibco). Cells were seeded into culture flasks containing expansion medium which was replaced every $24 \mathrm{~h}$ for 3 days to rid cultures of nonadherent contaminating cells.

\section{Isolation of guinea pig bone marrow-derived MSCs}

Femurs obtained from guinea pigs were transversely cut along the epiphysis, and the medullary cavity was flushed with expansion medium by using a 26-G needle to obtain a bone marrow suspension. To remove debris, the bone marrow suspension was filtered through a 40- $\mu \mathrm{m}$ Falcon cell strainer (In Vitro Technologies, Melbourne, Australia) before being seeded into culture flasks containing expansion medium. The medium was replaced every $24 \mathrm{~h}$ for 3 days.

\section{Cell culture and passaging}

MSCs derived from guinea pig bone marrow (gpBMMSCs) and adipose tissue (gpAT-MSCs) used in this study were cultured to the fourth passage for all subsequent experiments. Cells were plated at an initial density of 60 cells $/ \mathrm{cm}^{2}$ and incubated in expansion medium which was replenished every $48-72 \mathrm{~h}$ for 10-14 days until the cells were 70-85\% confluent (maximum). MSCs were trypsinised and either reseeded for expansion or collected for in vitro experiments and in vivo treatment of guinea pigs.

\section{Surface marker expression}

MSCs were immunolabelled as previously described [69] with CD29-Alexa Fluor 488 (clone TS2/16), CD34phycoerythrin (clone 581), CD45-PerCPCy5.5 (clone H130), CD44-Brilliant Violet 421 (clone IM7), CD73Brilliant Violet 421 (clone AD2) and CD90-Alexa Fluor 647 (clone 5E10) (1:100) (BioLegend, San Diego, CA, USA). Data were acquired on a BD FACSCanto II flow cytometer with FACSDiva version 6.1 software (BD Biosciences, Sydney, Australia). Unlabelled cells were incubated with 7-aminoactinomycin D (7-AAD) (1:20) (Life Technologies, Melbourne, Australia) for 1 minute before acquisition to determine the viability of the cell suspensions.

\section{Differentiation assay}

The differentiation potential of MSCs was assessed by using the StemPro Adipogenesis, Osteogenesis and Chondrogenesis Differentiation Kits in accordance with the instructions of the manufacturer (Life Technologies). To detect adipogenesis, MSCs were fixed in $10 \%$ neutral buffered formalin after 2 weeks in culture and 
lipid vacuoles were stained with Oil red O (Sigma-Aldrich, Sydney, Australia) in $60 \%$ (vol/vol) isopropanol. Cells were then counterstained with haematoxylin. To detect osteogenesis, MSCs were fixed in $10 \%$ neutral buffered formalin after 3 weeks in culture and calcium deposits were stained with $2 \%$ (wt/vol) Alizarin red S (SigmaAldrich) in distilled water. To determine chondrogenic differentiation, micromass pellets were fixed in $10 \%$ neutral buffered formalin after 2 weeks in culture and stained with Alcian blue 8GX (Sigma-Aldrich). Pellets were embedded in optimal cutting temperature (OCT) compound (Tissue-Tek; Sakura, Tokyo, Japan) and sectioned at $6 \mu \mathrm{m}$ for viewing under light microscopy.

\section{Colony-forming unit-fibroblast assay}

MSCs were seeded in 90-mm size petri dishes at low density (100 cells per dish). Expansion medium was changed every 3-4 days. After 2 weeks in culture, MSCs were fixed and stained with $0.5 \%$ (wt/vol) crystal violet (Sigma-Aldrich) in methanol for $30 \mathrm{~min}$ before colonies containing more than 50 cells (colony-forming unitfibroblast, or CFU-f) were counted under a dissection microscope.

\section{Growth kinetics}

MSCs were cultured in triplicates and seeded at 60 cells/ $\mathrm{cm}^{2}$ in $25-\mathrm{cm}^{2}$ cell culture flasks containing $5 \mathrm{ml}$ of expansion medium which was replaced every $48-72 \mathrm{~h}$. Cells were trypsinised and counted with a haemocytometer at days 3, 7 and 14. The population doubling level (PDL) was calculated by using the formula PDL $=\left(\log ^{2}\right.$ [final number of cells] $)-\left(\log ^{2}\right.$ [initial cells seeded] $)$ [70]

\section{Characterisation of MSC cell morphology}

MSCs were seeded at 100 cells $/ \mathrm{cm}^{2}$ in six-well plates and analysed after $48 \mathrm{~h}$. MSCs were morphologically characterised into one of two categories defined by the presence of elongated cell bodies with long thin processes (spindle) or flat bodies with irregular processes (flat).

\section{Induction of colitis}

To induce colitis, TNBS (Sigma-Aldrich) was dissolved in $30 \%$ ethanol to a concentration of $30 \mathrm{mg} / \mathrm{kg}$ and administered intrarectally $7 \mathrm{~cm}$ proximal to the anus (total volume of $300 \mu \mathrm{l}$ ) by a lubricated silicone catheter [43]. Guinea pigs were anesthetised with isoflurane (1-4 \% in $\mathrm{O}_{2}$ ) during the procedure and held at an inverted angle to prevent leakage. Sham-treated guinea pigs underwent the same procedure without administration of TNBS.

\section{Administration of MSCs}

Guinea pigs were treated with MSCs $3 \mathrm{~h}$ after TNBS administration at the peak of tissue damage [71]. MSCs were administered by enema at a dose of $1 \times 10^{6}$ cells in
$300 \mu \mathrm{l}$ of sterile phosphate-buffered saline (PBS). Guinea pigs were weighed and monitored daily following treatment. At 24 or $72 \mathrm{~h}$ after TNBS administration, animals were culled via stunning and exsanguination [63]. Segments of the distal colon were collected for histological and immunohistochemical studies.

\section{Tissue preparation}

Colon tissues were cut along the mesenteric border, stretched and pinned flat with the mucosal side up for wholemount preparations. Tissue samples were fixed overnight at $4{ }^{\circ} \mathrm{C}$ in Zamboni's fixative $(2 \%$ formaldehyde and $0.2 \%$ picric acid) and subsequently washed in dimethyl sulfoxide (DMSO) (Sigma-Aldrich) $(3 \times 10 \mathrm{~min})$ and PBS $(3 \times 10 \mathrm{~min})$ to remove fixative. Samples for histology were fixed in $10 \%$ buffered formalin solution and stored in $70 \%$ ethanol until embedding.

\section{Immunohistochemistry}

Immunohistochemistry was performed on wholemount preparations of the longitudinal muscle and myenteric plexus. The preparations were dissected by removing the mucosa, submucosa and circular muscle layers to expose the myenteric plexus. After 1-h incubation in $10 \%$ normal donkey serum (Merck Millipore, Melbourne, Australia) at room temperature, wholemount preparations were incubated overnight at $4{ }^{\circ} \mathrm{C}$ with primary antibodies: mouse anti-Hu (clone 15A7.1) (1:500) (Merck Millipore), goat anti-nNOS (1:500) (Novus Biologicals, Littleton, CO, USA), goat anti-ChAT (1:500) (Merck Millipore), mouse anti-CD45 (clone IH-1) (1:200) (Abcam, Melbourne, Australia) and rabbit anti-protein gene product 9.5 (PGP9.5) (1:500) (Abcam). Tissues were washed $(3 \times 10 \mathrm{~min}$ PBS $)$ and incubated for $2 \mathrm{~h}$ at room temperature with secondary antibodies: donkey anti-mouse Alexa Fluor 594 (1:200), donkey anti-goat FITC 488 (1:200), donkey anti-mouse FITC 488 (1:200) and donkey anti-rabbit Alexa Fluor 594 (1:200) (all from Jackson ImmunoResearch Laboratories, West Grove, PA, USA). After washing, tissues were mounted on glass slides with fluorescent mounting medium (Dako North America, Inc., Carpinteria, CA, USA). For cross-sections, tissues were frozen in OCT compound and sectioned at a thickness of $30 \mu \mathrm{m}$. Cross-sections were labelled with mouse anti-CD45 (1:200) followed by donkey anti-mouse FITC $488(1: 200)$ as described above.

\section{Histology}

Tissues were embedded in paraffin and cut into $5-\mu \mathrm{m}$ sections which were then deparaffinised, cleared, and rehydrated in graded ethanol. Cross-sections of the colon were stained with haematoxylin and eosin and mounted on glass slides with distrene plasticizer xylene (DPX) mountant. Gross morphological damage in cross- 
sections of the distal colon was assessed by histological grading of four parameters: mucosal flattening $(0=$ normal, 3 = severe flattening), occurrence of haemorrhagic sites $(0=$ none, $3=$ frequent sites $)$, loss of goblet cells $(0=$ normal, $3=$ severe loss of cells) and variation of the circular muscle $(0=$ normal, $3=$ considerable thickening of muscular layer) $[62,68]$.

\section{Flow cytometric analysis of transforming growth factor- $\beta 1$}

Conditioned media from MSC cultures as described above were collected at $48 \mathrm{~h}$ and analysed on the same day. Samples and cytokine standards with known concentrations were prepared in accordance with the instructions of the manufacturer by using the Human TGF- $\beta 1$ Single Plex Flex Set (BD Biosciences). Data were acquired by using a BD FACSCanto II flow cytometer with FACSDiva version 6.1 software. FCS files were exported from FACSDiva and analysed with FCAP array version 3 software (BD Biosciences) to produce standard curves and measurements of TGF- $\beta 1$ concentrations within the sample (in picograms per millilitre). At least 450 events were acquired per sample.

\section{Neuroprotective function of MSC-released TGF- $\beta 1$ in vitro}

Myenteric plexuses were isolated in accordance with a protocol described by Grundmann et al. [72]. Tissues were trypsinised for 10 min before cells were seeded into 96well plates pre-coated with Matrigel (BD Biosciences) diluted 1:10 in medium. Myenteric plexuses were cultured for 7 days with the medium changed every second day. Cultures were subjected to lipopolysaccharide (LPS) (100 ng/ml; Sigma-Aldrich) in conjunction with gpBMMSCs or gpAT-MSCs $\left(5 \times 10^{4}\right.$ cells per well), the TGF- $\beta$ receptor 1 (TGF- $\beta R 1)$ inhibitor SB431542 (10 $\mu \mathrm{M}$; SigmaAldrich) or DMSO as a vehicle control. After $3 \mathrm{~h}$, cultures were washed with PBS and fixed in $10 \%$ neutral buffered formalin for $1 \mathrm{~h}$. Cells were permeabilised with Triton X100 (Sigma-Aldrich) and incubated overnight at $4{ }^{\circ} \mathrm{C}$ with the pan-neuronal primary antibody chicken antimicrotubule-associated protein-2 (anti-MAP-2) (1:5000) followed by a 2 -h incubation with the secondary antibody donkey anti-chicken Alexa Fluor 594 (1:200).

\section{Imaging}

Confocal microscopy was performed by using an Eclipse Ti confocal laser scanning system (Nikon, Tokyo, Japan). Fluorophores were visualised by using a 488-nm excitation filter for Alexa 488 or FITC and a 559-nm excitation filter for Alexa 594. Z-series images were acquired at a nominal thickness of $0.5 \mu \mathrm{m}(512 \times$ 512 pixels). In wholemount preparations, the total numbers of myenteric neurons immunoreactive (IR) for $\mathrm{Hu}, \mathrm{nNOS}$, and ChAT as well as CD45-IR cells were counted within eight randomly captured images (total area size of $2 \mathrm{~mm}^{2}$ ) per preparation at a $\times 60$ magnification. To evaluate CD45-IR in cross-sections, eight randomly captured images were analysed by using ImageJ software (National Institutes of Health, Bethesda, MD, USA). Images were converted from red, green, and blue (RGB) to grayscale 8 bit then to binary; these images were then analysed to obtain the total number of CD45 immunoreactive cells within the mucosa, submucosa and muscle layers in a $650-\mu \mathrm{m}^{2}$ area $(512 \times 512$ pixels $)$. Chondrogenic pellets and haematoxylin and eosin-stained colon sections were visualised by using an Olympus BX53 microscope (Olympus, Melbourne, Australia), and images were captured with CellSens ${ }^{\text {Tw }}$ software (Olympus). Cellular imaging in vitro was performed on an Olympus IX81 inverted microscope using the same software. In primary neuronal cultures, images were acquired in a $9-\mathrm{mm}^{2}$ area and were analysed by using ImageJ software. Images were converted from RGB to grayscale 8 bit then to binary. From these images, the percentage area of MAP-2 immunoreactivity was measured and presented relative to untreated primary neuronal cultures to determine neuronal loss.

\section{Statistical analysis}

Data analysis was performed by using GraphPad Prism version 6 (Graphpad Software Inc., La Jolla, CA, USA). Data were analysed by using Student's $t$ test (two-tailed) and one- or two-way analysis of variance when appropriate for multiple group comparisons followed by Tukey's and Sidak's post hoc test. For all analysis, a $P$ value of less than 0.05 was considered significant. All data were presented as mean \pm standard error of the mean.

\section{Results}

In vitro validation of gpBM-MSCs and gpAT-MSCs and characterisation of their morphology and growth kinetics To examine the immunophenotype of guinea pig MSCs, cells were analysed by flow cytometry for the presence of positive MSC markers CD29, CD44, CD73 and CD90 and negative MSC markers CD34 (hematopoietic progenitors) and CD45 (leukocyte common antigen). Positive expression of CD29 was observed in both gpBM-MSCs (95.1\%) and gpAT-MSCs (97.6\%). There was differential expression of the CD73 antigen such that $85.0 \%$ of gpBM-MSCs expressed the antigen compared with negligible expression in gpAT-MSCs (0.2\%) (Fig. 1a). Negligible expression of the remaining surface markers was observed in both cell lines (gpBM-MSC: CD44, $1.9 \%$; CD90, $1.5 \%$; CD34, 4.4 \%; CD45, $5.5 \%$. gpAT-MSC: CD44, 0.2 \%; CD90, 0.2 \%; CD34, 0.2 \%; CD45, 0.7 \%; data not shown).

Both bone marrow- and adipose tissue-derived MSCs grew in monolayer culture, adhered to plastic, proliferated and were typical of MSC appearance (Fig. 1b, b'). 


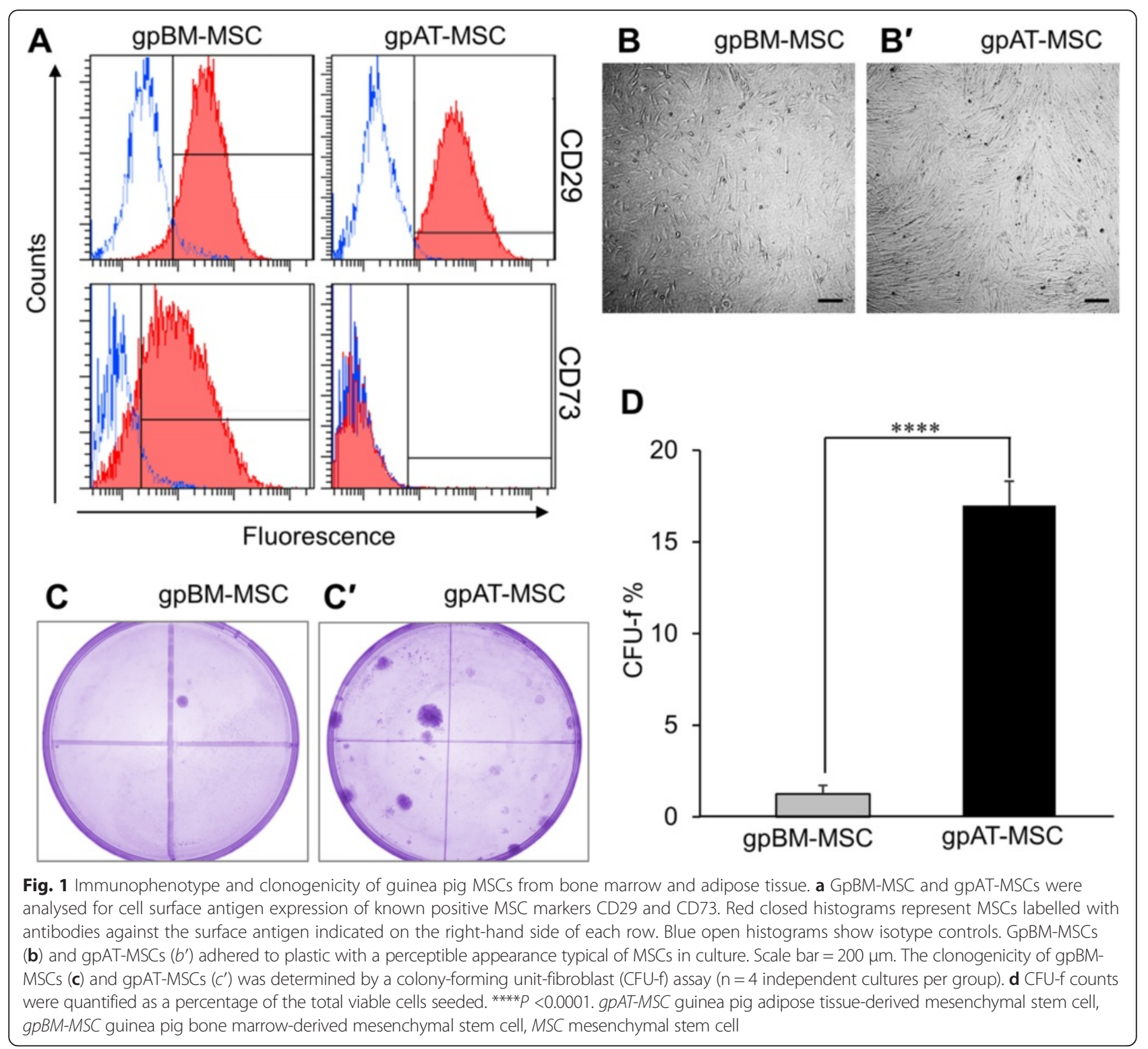

The clonogenicity of MSCs was compared via a CFU-f assay. The yield of colony-forming units $(>50$ cells per colony [73]) of gpAT-MSCs $(17.0 \pm 1.3 \%)$ was higher than that of gpBM-MSCs $(1.3 \pm 0.5 \%, P<0.0001)$ after 2 weeks in culture (Fig. 1c, $\mathrm{c}^{\prime}, \mathrm{d}, \mathrm{n}=4$ independent cultures per group). To assess the multipotent potential of MSCs, cells were cultured in specialised media to induce adipogenic, osteogenic and chondrogenic differentiation. Lipid vacuoles were present in MSCs cultured in adipogenesis differentiation medium when stained with Oil red $\mathrm{O}$ indicative of successful differentiation into adipocytes (Fig. 2a-b'). MSCs cultured in osteogenesis differentiation medium were stained with Alizarin red $\mathrm{S}$, confirming successful differentiation into osteocytes (Fig. $2 \mathrm{c}-\mathrm{d}^{\prime}$ ). MSCs seeded as micromass cultures only formed pellets in chondrogenesis differentiation medium. Chondrogenic differentiation was confirmed in the pellets by Alcian blue staining of cross-sections (Fig. 2e, f).

MSCs were categorised and quantified according to the shape of their cell bodies (Fig. 3a-b'). Both gpBM-MSCs and gpAT-MSCs exhibited two morphological types: long thin 'spindle' (Fig. 3a, b) and 'flat' with irregular processes (Fig. 3a', b'). Populations of cells with a 'spindle' morphology were higher in gpAT-MSCs $(63.3 \pm 4.9 \%)$ than gpBM-MSCs $(30.0 \pm 5.2 \%, P<0.001, \mathrm{n}=6$ independent cultures per group; Fig. 3c). Inversely, gpBM-MSC populations had a higher proportion of cells with a 'flat' morphology $(70.0 \pm 5.2 \%)$ in comparison with gpAT-MSCs $(36.7 \pm 4.9 \%, P<0.001)$. The proliferation of MSCs was quantified over 14 days in culture and presented as the 


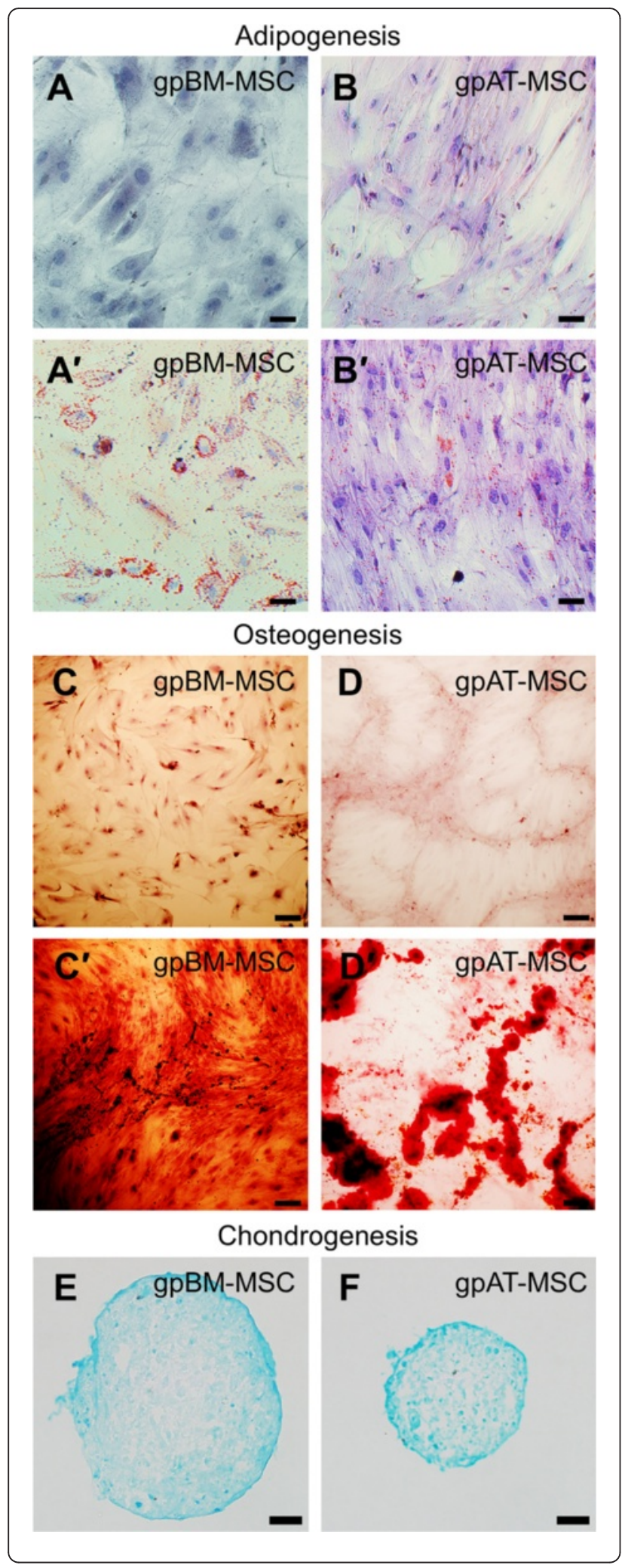

Fig. 2 Differentiation potential of guinea pig MSCs. GpBM-MSCs and gPAT-MSCs cultured without $(\mathbf{a}, \mathbf{b})$ and with $\left(a^{\prime}, b^{\prime}\right)$ adipogenesis differentiation medium for 14 days and stained with Oil red O. Scale bar $=50 \mu \mathrm{m}$. GpBM-MSCs and gpAT-MSCs cultured without (c, d) and with $\left(c^{\prime}, d^{\prime}\right)$ osteogenesis differentiation medium for 21 days and stained with Alizarin red S. Scale bar $=200 \mu \mathrm{m}$. Alcian blue stained cross-sections of chondrogenic pellets formed by gpBM-MSCs (e) and gpAT-MSCs $(\mathbf{f})$ after 14 days in chondrogenic differentiation medium. Scale bar $=50 \mu \mathrm{m}$. gpAT-MSC guinea pig adipose tissue-derived mesenchymal stem cell, gPBM-MSC guinea pig bone marrow-derived mesenchymal stem cell, MSC mesenchymal stem cell

population doubling level (PDL) (Fig. 3d). The PDL of gpAT-MSCs was higher than that of gpBM-MSCs at 3 days ( $2.6 \pm 0.1$ versus $0.5 \pm 0.5, P<0.01), 7$ days $(6.7 \pm 0.1$ versus $2.3 \pm 0.2, P<0.0001)$ and 14 days $(9.2 \pm 0.2$ versus $5.6 \pm$ $0.5, P<0.0001)$ in culture $(\mathrm{n}=3$ independent cultures per group per time point).

\section{GpBM-MSCs are more efficacious than gpAT-MSCs in ameliorating histological damage and weight loss associated with TNBS-induced colitis}

Gross morphological damage was not observed in haematoxylin and eosin-stained cross-sections from sham-treated guinea pigs (histological score = 0; Fig. 4a, a'). Mucosal flattening, haemorrhagic sites, loss of goblet cells and altered presentation of the circular muscle layer denoting histological score of 2-3 were observed at 24 and $72 \mathrm{~h}$ following induction of colitis (Fig. 4b, b'). Minimal evidence of mucosal damage or disruption to the colonic architecture was observed in sections of the colon from gpBM-MSC-treated animals at both 24 and $72 \mathrm{~h}$ after TNBS administration (histological score $=0-1$; Fig. 4c, $\mathrm{c}^{\prime}$ ). Structural changes in crypt architecture, mild mucosal damage and oedema in the submucosal layer were still present in colon sections from gpAT-MSC-treated animals (histological score $=1-2$; Fig. 4d, d').

The body weight of guinea pigs is indicative of overall disease progression. Guinea pig body weight was recorded at 24, 48 and $72 \mathrm{~h}$ after treatment (Fig. $4 \mathrm{e}$ and Table $1, \mathrm{n}=4$ animals per group per time point). No statistical differences were observed in weight change at $24 \mathrm{~h}$ between all groups. The body weight of TNBSadministered animals was lower compared with sham (48 h, $P<0.01$ and $72 \mathrm{~h}, P<0.0001$ ) and animals treated with gpBM-MSCs (48 h, $P<0.01$ and $72 \mathrm{~h}, P<0.001$ ) but not gpAT-MSCs ( $48 \mathrm{~h}, P=0.3$ and $72 \mathrm{~h}, P=0.7$ ). By $72 \mathrm{~h}$, gpBM-MSCs were more effective than gpAT-MSCs in promoting weight gain $(P<0.05)$. At the same time point, only sham and gpBM-MSC groups had gained weight (both $P<0.0001$ ) which was not observed in TNBS $(P=1.0)$ or gpAT-MSC $(P=0.6)$ groups. 

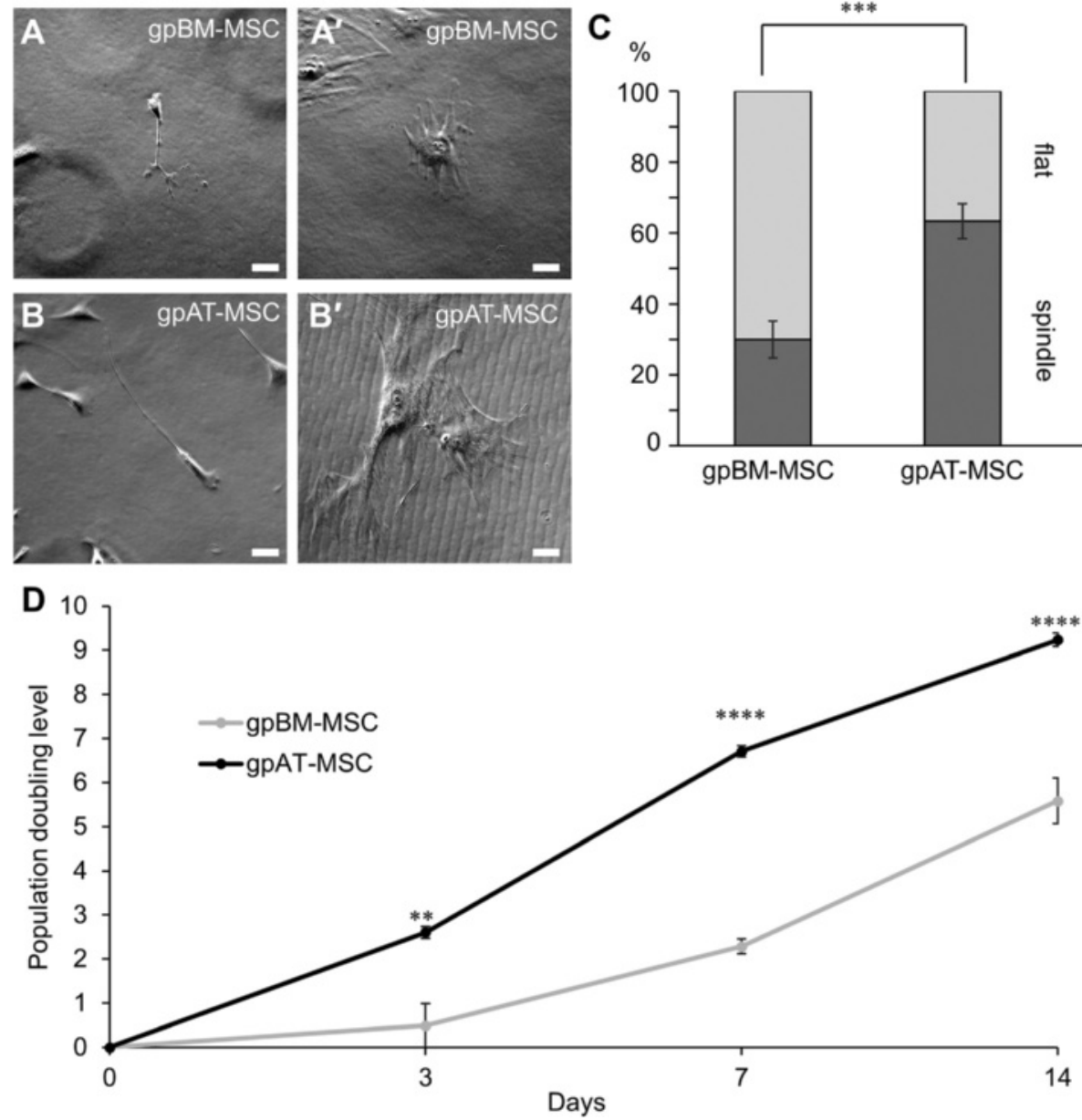

Fig. 3 In vitro morphology and growth kinetics of guinea pig MSCs. a- $b^{\prime}$ Distinct morphological subpopulations were exhibited by gpBM-MSCs $\left(\mathbf{a}, a^{\prime}\right)$ and gpAT-MSCs $\left(\mathbf{b}, b^{\prime}\right)$ in culture. MSC morphology was defined according to the presence of long thin spindles ('spindle': $\left.\mathbf{a}, \mathbf{b}\right)$ or flat cells with atypical processes ('flat': $\left.a^{\prime}, b^{\prime}\right)$ (scale bar $=50 \mu \mathrm{m}$ ). c Quantitative analysis of MSC morphological types. Data are expressed as a percentage of the total cell number in each population ( $n=6$ independent cultures per group). $\mathbf{d}$ The population doubling level of proliferating MSCs was recorded at 3, 7 and 14 days after seeding ( $n=3$ independent cultures per group per time point). ${ }^{* *} P<0.01,{ }^{* * *} P<0.001$, ${ }^{* * * *} P<0.0001$. gpAT-MSC guinea pig adipose tissue-derived mesenchymal stem cell, gPBM-MSC guinea pig bone marrow-derived mesenchymal stem cell, MSC mesenchymal stem cell

\section{GpBM-MSCs are more efficient in attenuating leukocyte infiltration to the mucosa and myenteric ganglia compared with gpAT-MSCs}

Leukocyte infiltration to the mucosa, submucosa and muscle layers was quantified in cross-sections of the guinea pig colon by using an antibody to the panleukocyte marker CD45 (Fig. 5a-d', $\mathrm{n}=4$ animals per group per time point). Administration of TNBS resulted in an increase in leukocytes at 24 and $72 \mathrm{~h}$ within the mucosa $(24$ and $72 \mathrm{~h}, P<0.0001)$ and submucosa (24 h, $P<0.001$ and $72 \mathrm{~h}, P<0.0001$ ) (Table 2 and Fig. 5e). Greater leukocyte numbers in TNBS groups were attenuated by treatments with both gpBM-MSCs and gpATMSCs at 24 and $72 \mathrm{~h}$ in the mucosa (gpBM-MSC: 24 and $72 \mathrm{~h}, P<0.01$; gpAT-MSCs: $24 \mathrm{~h}, P<0.05$ and $72 \mathrm{~h}$, $P<0.01)$ and submucosa (gpBM-MSC: $24 \mathrm{~h}, P<0.05$ and $72 \mathrm{~h}, P<0.0001$; gpAT-MSCs: $24 \mathrm{~h}, P<0.05$ and $72 \mathrm{~h}, P<0.001)$. However, at $24 \mathrm{~h}$, leukocyte numbers were higher in the mucosa of gpAT-MSC-treated animals compared with shams $(P<0.05)$. No differences in leukocyte infiltration were observed in crosssections of the muscle layer. Leukocyte infiltration to the level of the myenteric plexus was quantified in wholemount preparations of the guinea pig colon (Fig. $6 \mathrm{a}-\mathrm{d}^{\prime}, \mathrm{n}=4$ animals per group per time point). At $24 \mathrm{~h}$, leukocyte numbers were elevated in animals administered with TNBS only $(107.8 \pm 7.2$ cells per area) compared with shams $(19 \pm 1.2$ cells per area, $P<0.0001$; Fig. 6e). The infiltration of leukocytes was attenuated by treatment with both gpBM-MSCs $(22 \pm 2.9$ cells per area, $P<0.0001)$ and gpAT-MSCs $(62 \pm 4.6$ cells per area, $P<0.001)$. However, in the latter, leukocytes were 

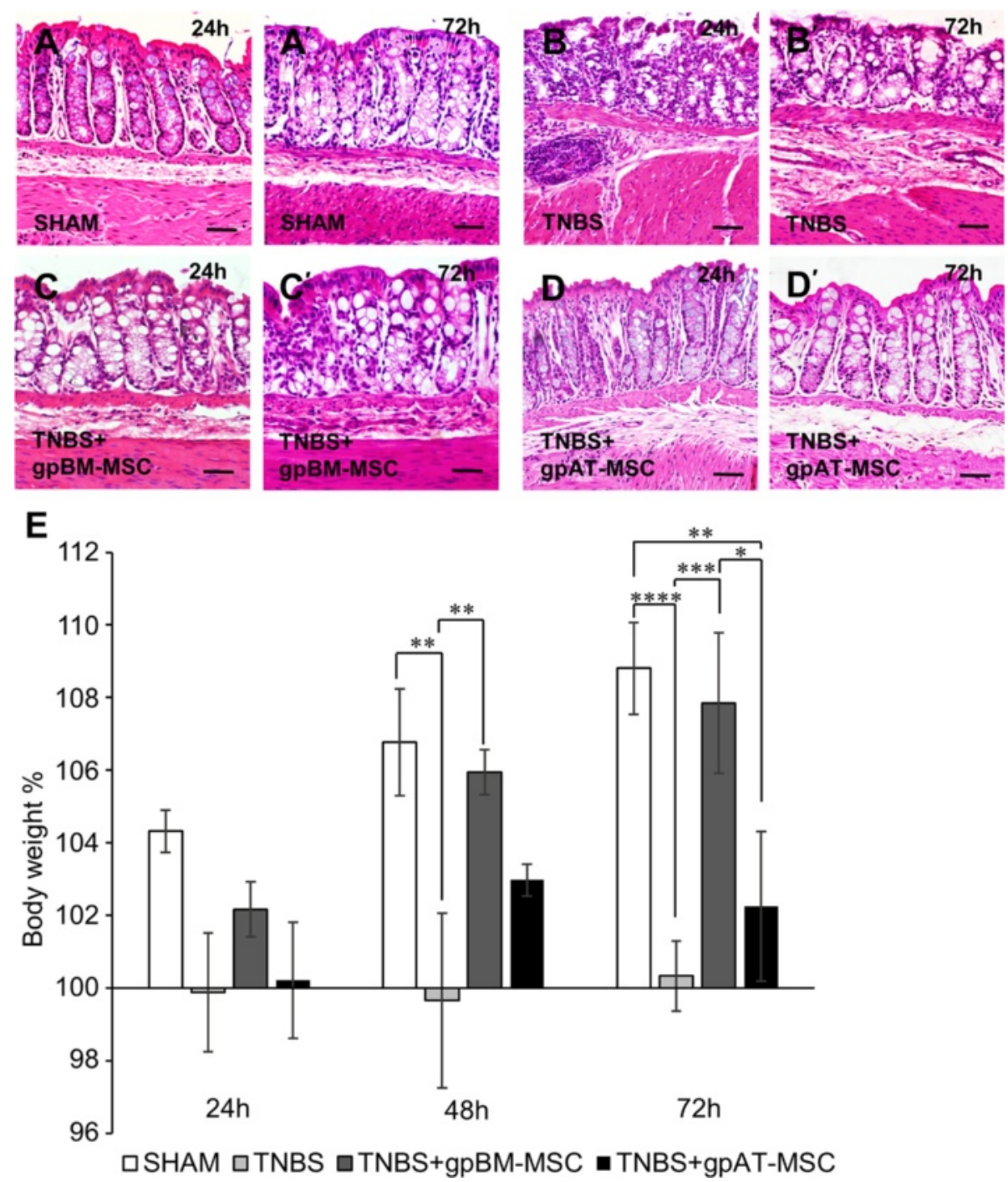

Fig. 4 Effects of guinea pig MSC treatments on histological changes and body weight in colitis. Colonic structure was assessed via haematoxylin-and-eosin staining of cross-sections from tissues collected at $24 \mathrm{~h}(\mathbf{a}-\mathbf{d})$ and $72 \mathrm{~h}\left(a^{\prime}-d^{\prime}\right)$ after TNBS administration. Scale bar $=50 \mu \mathrm{m}$. e Body weight was recorded at 24,48 and $72 \mathrm{~h}$ after TNBS administration and is expressed as the change from baseline measurements. ${ }^{*} P<0.05$, ${ }^{* *} P<0.01,{ }^{* * *} P<0.001$, ${ }^{* * *} P<0.0001$, significantly different between groups; ${ }^{\dagger+t} p<0.001$, ${ }^{+t+\dagger} p<0.0001$, significantly different from baseline weight within groups, $n=4$ animals per group per time point. gpAT-MSC guinea pig adipose tissue-derived mesenchymal stem cell, gpBM-MSC guinea pig bone marrow-derived mesenchymal stem cell, MSC mesenchymal stem cell, TNBS 2,4,6-trinitrobenzene sulfonic acid

Table 1 Effects of allogeneic mesenchymal stem cells derived from guinea pigs on body weight (percentage) in TNBS-induced colitis

\begin{tabular}{lllcr}
\hline & Sham & TNBS & TNBS + gpBM-MSC & TNBS + gpAT-MSC \\
\hline $24 \mathrm{~h}$ & $104.3 \pm 0.6$ & $99.9 \pm 1.6$ & $102.2 \pm 0.8$ & $100.2 \pm 1.6$ \\
$48 \mathrm{~h}$ & $106.8 \pm 1.5$ & $100.4 \pm 2.4+\dagger$ & $105.9 \pm 0.6^{* *}$ & $103.0 \pm 0.4$ \\
$72 \mathrm{~h}$ & $108.8 \pm 1.3$ & $100.3 \pm 1.0+\dagger+\dagger$ & $107.8 \pm 1.9^{* * *}$ & $102.3 \pm 2.1 \neq+\dagger$ \\
\hline
\end{tabular}

TNBS 2,4,6-trinitrobenzene sulfonic acid, gpBM-MSC guinea pig bone marrow-derived mesenchymal stem cell, gpAT-MSC guinea pig adipose tissue-derived mesenchymal stem cell. ${ }^{* *} P<0.01,{ }^{* * *} P<0.001$, significantly different from TNBS; $+\uparrow P<0.01,++\dagger+P<0.0001$ significantly different from sham; $¥ P<0.05$, significantly different from gpBM-MSC 

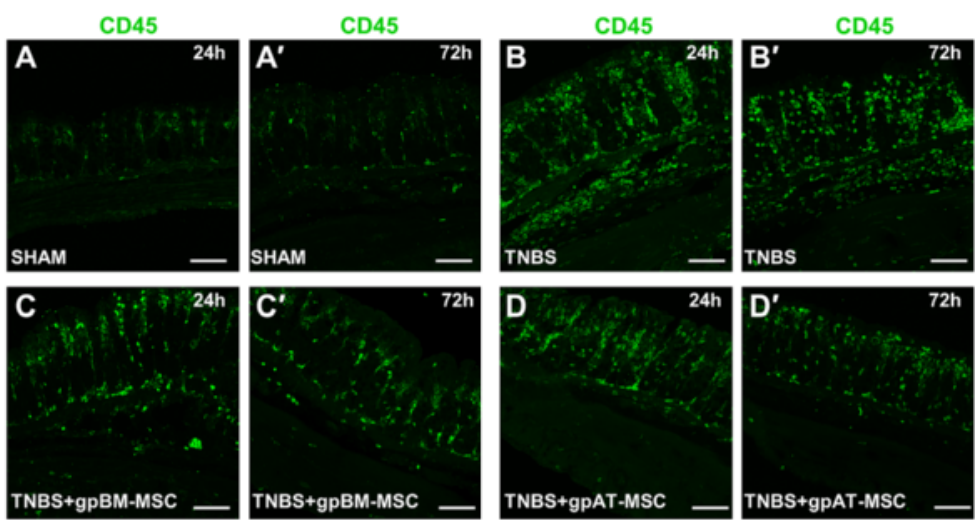

E

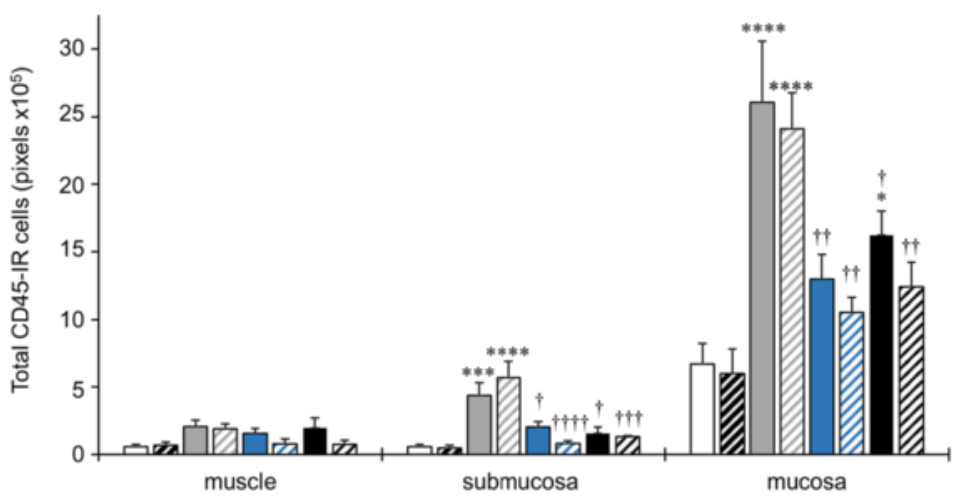

口SHAM 24h घTNBS 24h घTNBS+gpBM-MSC 24h $\bullet$ TNBS+gpAT-MSC $24 h$

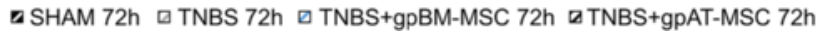

Fig. 5 Effects of guinea pig MSC treatments on leukocyte infiltration in the colonic wall. a- $d^{\prime}$ CD45-IR leukocytes were visualised within the mucosa, submucosa and muscle layers of the colon. Cross-sections from guinea pig colon collected at $24 \mathrm{~h}(\mathbf{a}-\mathbf{d})$ and $72 \mathrm{~h}\left(a^{\prime}-d^{\prime}\right)$ after treatment. Scale bar $=100 \mu \mathrm{m}$. e All of the CD45-IR cells were quantified in the mucosa, submucosa and muscle layers within a $650-\mu m^{2}$ area of the colon. ${ }^{*} P<0.05,{ }^{* * *} P<0.001,{ }^{* * *} P<0.0001$, significantly different from sham; $+P<0.05,+\dagger P<0.01$, $+\dagger+P<0.001,+\dagger \dagger+P<0.0001$, significantly different from TNBS; $n=4$ animals per group per time point. gPAT-MSC guinea pig adipose tissue-derived mesenchymal stem cell, gpBM-MSC guinea pig bone marrow-derived mesenchymal stem cell, MSC mesenchymal stem cell, TNBS 2,4,6-trinitrobenzene sulfonic acid

Table 2 Effects of in vivo treatment with allogeneic mesenchymal stem cells derived from guinea pigs on CD45 immunoreactive leukocytes (pixels $\times 10^{5}$ ) in cross-sections of the colon

\begin{tabular}{|c|c|c|c|c|}
\hline & Sham & TNBS & TNBS + gpBM-MSC & TNBS + gpAT-MSC \\
\hline & Mucosa & & & \\
\hline $24 \mathrm{~h}$ & $6.71 \pm 1.52$ & $26.09 \pm 4.47^{* * * *}$ & $12.97 \pm 1.83+\dagger$ & $16.22 \pm 1.80 \dagger^{*}$ \\
\hline \multirow[t]{2}{*}{$72 \mathrm{~h}$} & $6.00 \pm 1.82$ & $24.13 \pm 2.65^{* * * *}$ & $10.54 \pm 1.11+\dagger$ & $12.44 \pm 1.78+\dagger$ \\
\hline & Submucosa & & & \\
\hline $24 \mathrm{~h}$ & $0.59 \pm 0.17$ & $4.38 \pm 0.92^{* * *}$ & $2.02 \pm 0.41 \dagger$ & $1.56 \pm 0.46 \dagger$ \\
\hline \multirow[t]{2}{*}{$72 \mathrm{~h}$} & $0.48 \pm 0.20$ & $5.69 \pm 1.22^{* * * *}$ & $0.82 \pm 0.19+\uparrow+\dagger$ & $1.31 \pm 0.10+\uparrow \dagger$ \\
\hline & Muscle & & & \\
\hline $24 \mathrm{~h}$ & $0.57 \pm 0.19$ & $2.07 \pm 0.48$ & $1.55 \pm 0.38$ & $1.96 \pm 0.74$ \\
\hline $72 \mathrm{~h}$ & $0.68 \pm 0.22$ & $1.91 \pm 0.36$ & $0.78 \pm 0.39$ & $0.76 \pm 0.30$ \\
\hline
\end{tabular}

TNBS 2,4,6-trinitrobenzene sulfonic acid, gpBM-MSC guinea pig bone marrow-derived mesenchymal stem cell, gpAT-MSC guinea pig adipose tissue-derived mesenchymal stem cell. $+P<0.05,+\dagger P<0.01,++\uparrow P<0.001,+\dagger+\dagger P<0.0001$, significantly different from TNBS; ${ }^{*} P<0.05,{ }^{* * *} P<0.001, * * * P<0.0001$, significantly different from sham; $\mathrm{n}=4$ animals per group per time point 

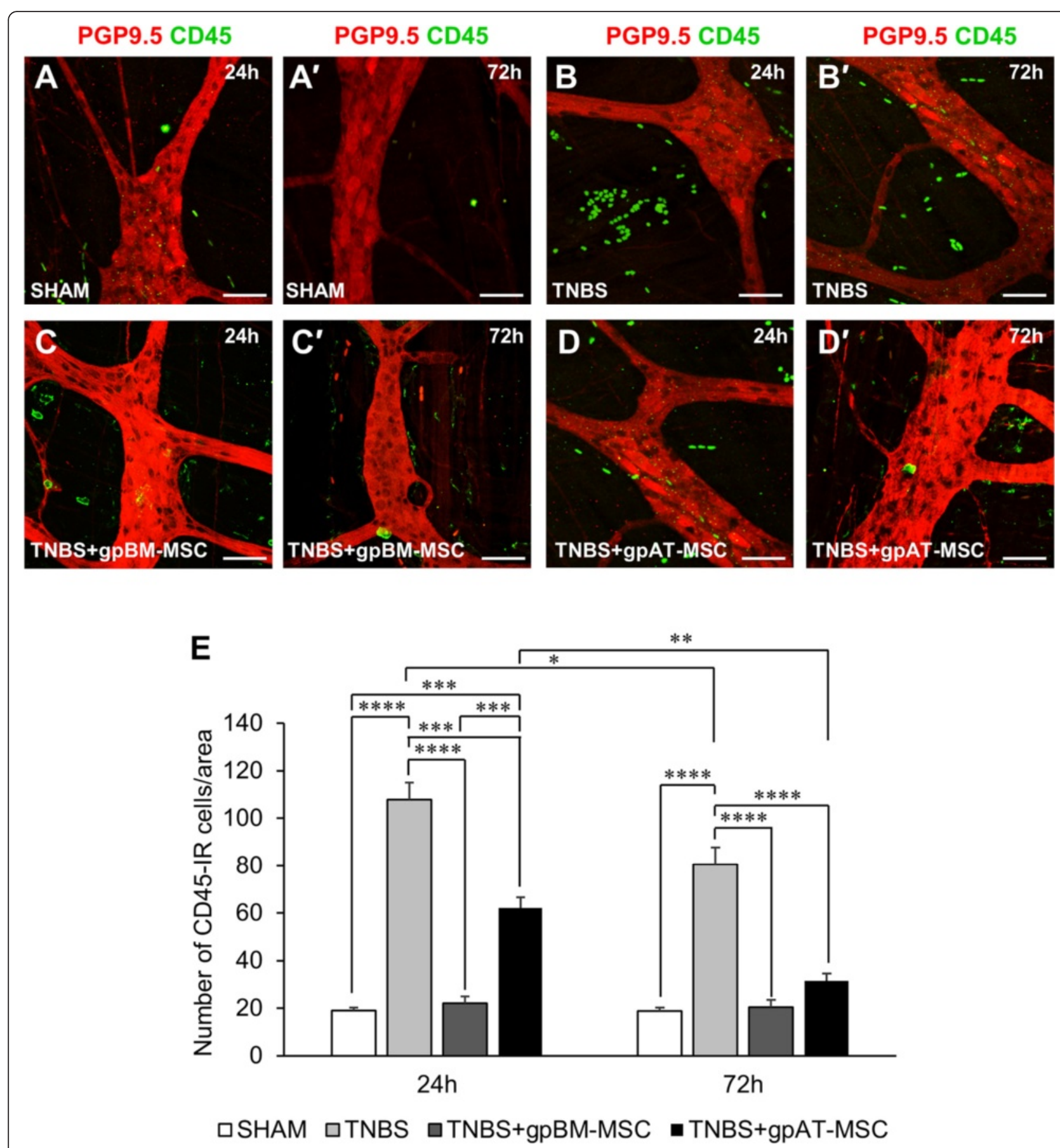

Fig. 6 Effects of treatments with guinea pig MSCs on leukocyte infiltration to the myenteric plexus. a- $d^{\prime}$ CD45-IR leukocytes (green) were visualised on the level of myenteric neurons labelled with anti-PGP9.5 (red) by confocal microscopy. Wholemounts of the myenteric plexus from guinea pig colon preparations collected at $24 \mathrm{~h}(\mathbf{a}-\mathbf{d})$ and $72 \mathrm{~h}\left(a^{\prime}-d^{\prime}\right)$ after treatment. Scale bar $=50 \mu \mathrm{m}$. e CD45-IR leukocytes were quantified in a 2-mm ${ }^{2}$ area of the myenteric plexus in the colon. ${ }^{* *} P<0.01,{ }^{* *} P<0.001,{ }^{* * *} P<0.0001, \mathrm{n}=4$ animals per group per time point. gpAT-MSC guinea pig adipose tissuederived mesenchymal stem cell, gpBM-MSC guinea pig bone marrow-derived mesenchymal stem cell, MSC mesenchymal stem cell, $P G P 9.5$ protein gene product 9.5

still elevated compared with sham $(P<0.001)$ and gpBMMSC $(P<0.001)$ treated animals. At $72 \mathrm{~h}$, the number of leukocytes remained elevated in TNBS-administered animals (80.5 \pm 7.3 cells per area) compared with sham
$(18.8 \pm 1.4$ cells per area, $P<0.0001)$ which was decreased by both gpBM-MSC $(20.5 \pm 3.1$ cells per area, $P<0.0001)$ and gpAT-MSC $(31.5 \pm 3.2$ cells per area, $P$ $<0.0001)$ treatments to levels comparable to those of the 
sham group. Between 24 and $72 \mathrm{~h}$, there was no change in the levels of leukocytes in sham $(P>0.99)$ and gpBM-MSC-treated $(P>0.99)$ groups. Conversely, a decrease in the number of leukocytes was observed in TNBS $(P<0.05)$ and gpAT-MSC-treated $(P<0.01)$ groups.

\section{GpBM-MSCs and gpAT-MSCs have comparable efficacy for attenuating inflammation-induced enteric neuropathy}

To assess the effect of MSC treatments on the total number of myenteric neurons, anti-HuC/D antibody was used as a pan-neuronal marker in wholemount preparations of the guinea pig colon and quantified per $2-\mathrm{mm}^{2}$ area (Fig. $7 \mathrm{a}-\mathrm{d}^{\prime}, \mathrm{n}=4$ animals per group per time point). The number of neurons in the myenteric plexus was reduced after TNBS administration compared with sham treatment at both $24 \mathrm{~h}(P<0.0001)$ and $72 \mathrm{~h}(P<0.001$; Table 3 and Fig. 7e). The loss of myenteric neurons was alleviated by treatment with both gpBM-MSCs (24 and $72 \mathrm{~h}: P<0.05)$ and gpAT-MSCs $(24 \mathrm{~h}: P<0.01$ and $72 \mathrm{~h}: P<0.05)$.

The two major subpopulations of neurons in the myenteric plexus, inhibitory and excitatory muscle motor and interneurons, were investigated [74]. Inhibitory neurons were labelled with anti-nNOS antibody (Fig. 8a-d'), and the total number of nNOS-IR neurons was quantified per 2- $\mathrm{mm}^{2}$ area (Fig. 8e and Table 3, $\mathrm{n}=4$ animals per group per time point). The number of nNOS-IR neurons was increased in the myenteric plexus from TNBS groups compared with sham at $24 \mathrm{~h}(P<0.01)$ and $72 \mathrm{~h}(P<0.05)$. The proportion of nNOS-IR neurons to the total number of $\mathrm{Hu}-\mathrm{IR}$ neurons was increased in TNBS groups at both time points compared with sham ( 24 and $72 \mathrm{~h}, P<0.001$ ) (Fig. 8f, $\mathrm{n}=4$ animals per group per time point). Both MSC treatments ameliorated the increase in the total number (gpBM-MSC: 24 and $72 \mathrm{~h}, P<0.05$ and gpATMSC: 24 and $72 \mathrm{~h}, P<0.01)$ and proportion of nNOS-IR neurons at all time points (gpBM-MSC: 24 and $72 \mathrm{~h}$, $P<0.01$; gpAT-MSCs: $24 \mathrm{~h}, P<0.001$ and $72 \mathrm{~h}, P<0.01$ ) (Fig. 8e, f and Table 3).

Excitatory muscle motor and interneurons were labelled with anti-ChAT antibodies (Fig. 9a-d'). Quantification of ChAT-IR neurons revealed a decrease in the total number of neurons at both 24 and $72 \mathrm{~h}$ after TNBS administration compared with sham $(P<0.0001$ for both) (Fig. 9e and Table 3, $\mathrm{n}=4$ animals per group per time point). The number of ChAT-IR neurons was higher in groups treated with gpBM-MSCs and gpAT-MSCs compared with TNBS alone at both time points $(P<0.01$ for all $)$ but was less than in shams $(P<0.05$ for all). The proportion of ChATIR neurons to the total number of $\mathrm{Hu}-\mathrm{IR}$ neurons was quantified; however, no differences were observed between treatment groups $(P=0.21)$ (Fig. 9f).
TGF- $\beta 1$ secreted by guinea pig MSCs attenuates neuronal loss in vitro

TGF- $\beta 1$ is a potent anti-inflammatory and neuroprotective cytokine highly conserved between species. MSCs were cultured for $48 \mathrm{~h}$ before the medium was collected for flow cytometric quantification of TGF- $\beta 1$. The in vitro secretion of TGF- $\beta 1$ by both gpBM-MSCs $(88.4 \pm 13.7 \mathrm{pg} /$ $\mathrm{ml})$ and gpAT-MSCs $(88.7 \pm 11.5 \mathrm{pg} / \mathrm{ml})$ was observed. The expansion medium alone served as a control and also contained TGF- $\beta 1(32.4 \pm 11.2 \mathrm{pg} / \mathrm{ml})$, albeit to a lesser extent than MSC-conditioned media (both $P<0.05$ ) (Fig. 10a, a').

Primary myenteric neurons were isolated to study the role of TGF- $\beta 1$ in MSC-mediated neuroprotection in vitro (Fig. 10b). Inflammatory conditions were simulated by incubation with LPS (100 ng/ml) for $3 \mathrm{~h}$. Neuronal loss was observed in cultures incubated with LPS alone $(44.4 \pm 6.5 \%)$ or in combination with the vehicle DMSO $(47.3 \pm 6.2 \%)$ or the TGF- $\beta$ R1 inhibitor, SB431542 (47.7 $\pm 5.2 \%)(P<0.0001$ for all $)$. Neuronal loss was partly attenuated when neurons were co-cultured with gpBM-MSCs and $(83.3 \pm 6.6 \%)$ gpAT-MSCs $(82.5 \pm 4.3 \%)$ in comparison with LPS alone and LPS with DMSO ( $P<0.001$ for all). The survival of myenteric neurons was decreased by the addition of SB431542 to cocultures of neurons with gpBM-MSC $(52.0 \pm 5.6 \%, P$ $<0.05)$ or gpAT-MSC $(57.8 \pm 2.2 \%, P<0.01)$.

\section{Discussion}

This study is the first that has evaluated the functional capacity of guinea pig bone marrow and adipose tissue-derived MSCs and determined their therapeutic value in an animal model of colitis. In vitro characterisation revealed distinct differences in growth kinetics, clonogenicity and cell morphology between MSCs derived from bone marrow and adipose tissue. In an in vivo model of TNBS-induced colitis, gpBM-MSCs were comparatively more efficacious than gpAT-MSCs in attenuating weight loss, colonic tissue damage and leukocyte infiltration into the myenteric plexus. MSCs from both sources were equally neuroprotective in the amelioration of enteric neuronal loss and changes to the neurochemical coding of neuronal subpopulations.

MSCs were validated and characterised according to the International Society for Cellular Therapy guidelines [9]. Evaluation of surface phenotype revealed that both gpBM-MSCs and gpAT-MSCs were positive for CD29 expression. Guinea pig MSCs were negative for the expression of endothelial and haematopoietic lineage markers, CD34 and CD45. Previous use of antibodies targeting human surface marker epitopes in guinea pigs has provided evidence for cross-reactivity in CD34 and CD45 [75]; however, the possibility of false-negative results 


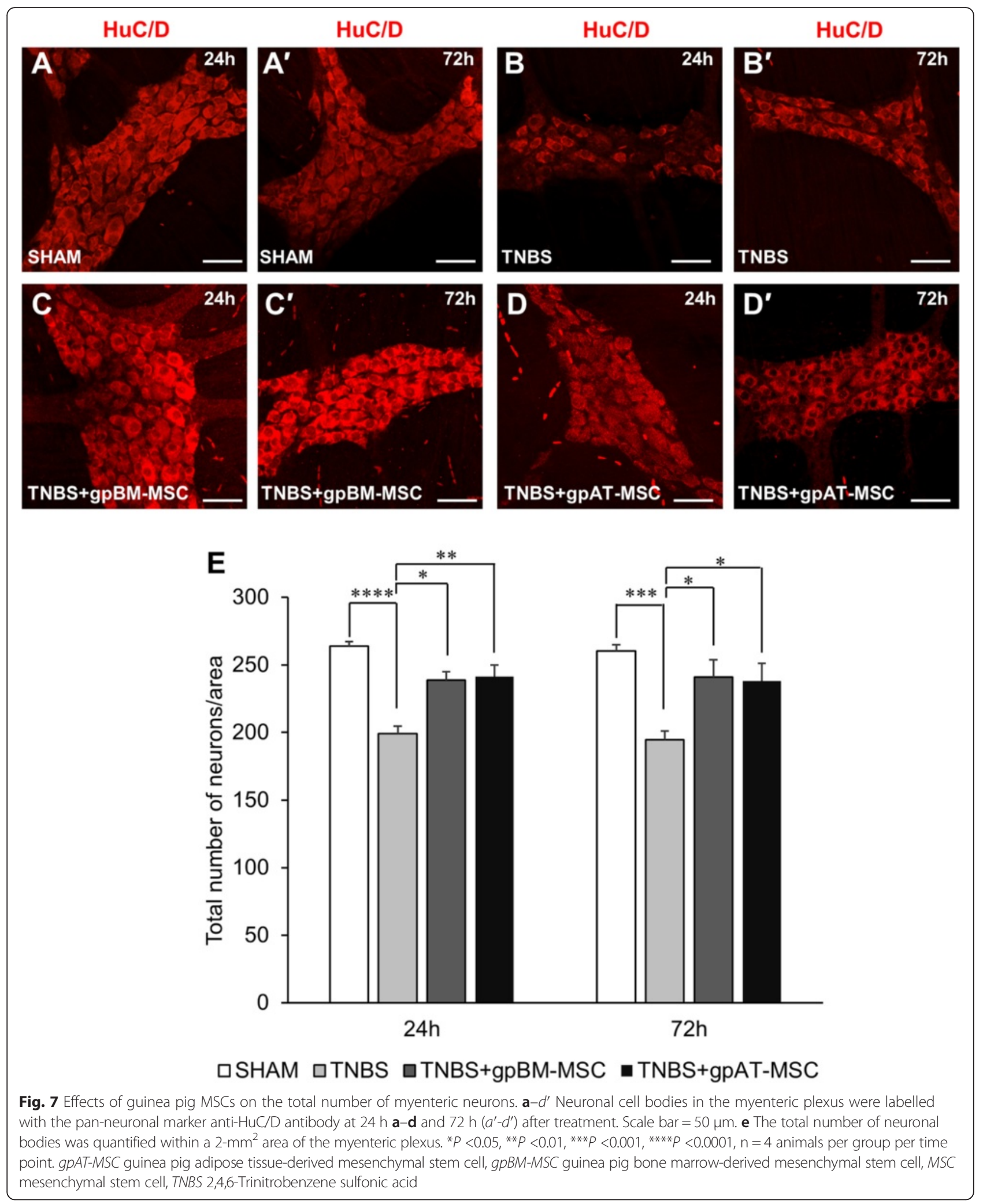

cannot be ruled out entirely. Expression of CD44 and CD90 was negligible in both types of guinea pig MSCs, and CD73 was observed only in gpBM-MSCs. The lack of
CD73 expression in adipose tissue-derived MSCs has been previously reported in mouse [76]. Similar to other MSCs, gpAT-MSCs were adherent to plastic and successfully 
Table 3 Effects of allogeneic mesenchymal stem cells derived from guinea pigs on myenteric neurons in TNBS-induced colitis

\begin{tabular}{|c|c|c|c|c|}
\hline & Sham & TNBS & TNBS + gpBM-MSC & TNBS + gpAT-MSC \\
\hline & \multicolumn{4}{|c|}{ Total number of myenteric neurons $/ 2 \mathrm{~mm}^{2}$} \\
\hline $24 \mathrm{~h}$ & $262.6 \pm 2.9$ & $204.6 \pm 6.9+†+\dagger$ & $238.8 \pm 6.2^{*}$ & $241.3 \pm 8.6^{* *}$ \\
\hline \multirow[t]{2}{*}{$72 \mathrm{~h}$} & $261.8 \pm 3.9$ & $203.4 \pm 4.2+\dagger \dagger$ & $241.0 \pm 12.7^{*}$ & $238.0 \pm 13.2^{*}$ \\
\hline & \multicolumn{4}{|c|}{ Total number of nNOS-IR neurons $/ 2 \mathrm{~mm}^{2}$} \\
\hline $24 \mathrm{~h}$ & $51.8 \pm 1.5$ & $68.8 \pm 3.9+\dagger$ & $58.5 \pm 4.3^{*}$ & $55.5 \pm 4.4^{* *}$ \\
\hline \multirow[t]{2}{*}{$72 \mathrm{~h}$} & $53.0 \pm 1.0$ & $67.6 \pm 3.8+$ & $56.0 \pm 5.5^{*}$ & $55.8 \pm 1.8^{* *}$ \\
\hline & \multicolumn{4}{|c|}{ Proportion of nNOS-IR neurons $/ 2 \mathrm{~mm}^{2}, \%$} \\
\hline $24 \mathrm{~h}$ & $19.8 \pm 0.8$ & $33.8 \pm 2.4 \dagger+\dagger$ & $24.6 \pm 2.2^{* *}$ & $23.0 \pm 1.7^{* * *}$ \\
\hline \multirow[t]{2}{*}{$72 \mathrm{~h}$} & $20.3 \pm 0.3$ & $33.3 \pm 1.9+1 \dagger$ & $23.3 \pm 2.0^{* *}$ & $23.6 \pm 1.3^{* *}$ \\
\hline & \multicolumn{4}{|c|}{ Total number of ChAT-IR neurons $/ 2 \mathrm{~mm}^{2}$} \\
\hline $24 \mathrm{~h}$ & $159.6 \pm 3.9$ & $111.4 \pm 4.0+†+\dagger$ & $134.3 \pm 5.7 十^{* *}$ & $135.3 \pm 5.7 十^{* *}$ \\
\hline \multirow[t]{2}{*}{$72 \mathrm{~h}$} & $157.4 \pm 4.5$ & $110.2 \pm 2.2+† \dagger \dagger$ & $137.8 \pm 1.5 十^{* *}$ & $135.3 \pm 2.5 t^{* *}$ \\
\hline & \multicolumn{4}{|c|}{ Proportion of ChAT-IR neurons/2 mm², \% } \\
\hline $24 \mathrm{~h}$ & $60.8 \pm 1.6$ & $54.6 \pm 2.3$ & $56.7 \pm 4.1$ & $56.0 \pm 1.3$ \\
\hline $72 \mathrm{~h}$ & $60.1 \pm 1.2$ & $54.3 \pm 2.0$ & $57.6 \pm 3.0$ & $57.2 \pm 2.1$ \\
\hline
\end{tabular}

TNBS 2,4,6-trinitrobenzene sulfonic acid, gpBM-MSC guinea pig bone marrow-derived mesenchymal stem cell, gpAT-MSC guinea pig adipose tissue-derived mesenchymal stem cell, $n N O S$ neuronal nitric oxide synthase, ChAT choline acetyltransferase, $I R$ immunoreactive. $+P<0.05,+\dagger P<0.01,+t+P<0.001$, $++t+P<0.0001$, significantly different from sham; ${ }^{*} P<0.05, * * P<0.01,{ }^{* * * P}<0.001$, significantly different from TNBS

differentiated into adipocytes, osteocytes and chondrocytes when supplemented with relevant differentiation media. These traits were previously used to define cells from the guinea pig as MSCs by Frölich et al. [77] in the only other study characterising these cells. Our data demonstrated that gpAT-MSCs have greater proliferative capacity than gpBM-MSCs and this is in agreement with their study [77]. These observations are consistent with studies in mouse and human MSCs derived from bone marrow and adipose tissue $[27,78,79]$.

Clonogenicity is an important characteristic of MSCs and is considered to be predictive of their proliferative and functional capacity [80]. Our data indicate that gpATMSCs have an approximately 13-fold higher proportion of cells able to form colonies compared with gpBM-MSCs. Decreased colony formation has been observed in human bone marrow MSCs compared with adipose tissue MSCs with CFU-f counts continuing to decline through to the fourth passage [78]. The CFU-f values of passage four guinea pig MSCs used in our study were comparable to the ranges observed by Schellenberg et al. [80] in multiple human bone marrow and adipose tissue cell lines at the same passage.

High proliferation rate and spindle-shaped morphology are desired qualities of MSCs; optimising isolation and in vitro conditions to maintain these traits is one of the key focuses of MSC research [81-83]. In our study, gpAT-MSCs appeared to have better MSC qualities in standard culture, including higher proliferation rate, colony-forming potential and proportions of spindleshaped cells. Comparatively, these traits were suboptimal in gpBM-MSCs. These results may be directly related to the heterogeneous subpopulations within MSC cultures [84]. Similar to our observations in guinea pig MSCs, it has been reported that rat MSCs from adipose tissue are more spindle-shaped and have a higher proliferative capacity than those from bone marrow [85]. Given these data, characterisation of MSCs on the basis of morphology could be predictive of in vitro proliferation and clonogenicity. Thus, differences between the in vitro properties of MSCs from bone marrow and adipose tissue are regularly observed in various species. However, there is a lack of research providing comparative evaluation of the therapeutic efficacy of MSCs derived from different tissues in in vivo models of disease.

One of the common models of intestinal inflammation employs TNBS administration into the colon which activates the immune response mediated by $T$ helper type 1 cells to hapten-modified autologous proteins [86]. Lack of weight gain is a symptom of TNBS-induced colitis, reflecting the general condition of the animal during the inflamed state $[65,87]$. In our study, gpBM-MSCtreated, but not gpAT-MSC-treated, animals gained weight by $72 \mathrm{~h}$ after the induction of colitis. The absence of the cell surface enzyme CD73 (5' -nucleotidase) in gpAT-MSCs may be a contributing factor as the conversion of adenosine monophosphate to extracellular adenosine by CD73 plays a key role in suppressing the inflammatory response and the $\mathrm{T}$ helper type 1 pathway [88]. In our study, gpBM-MSCs alleviated gross morphological changes in histological cross-sections of the colon. Conversely, oedema was observed after 


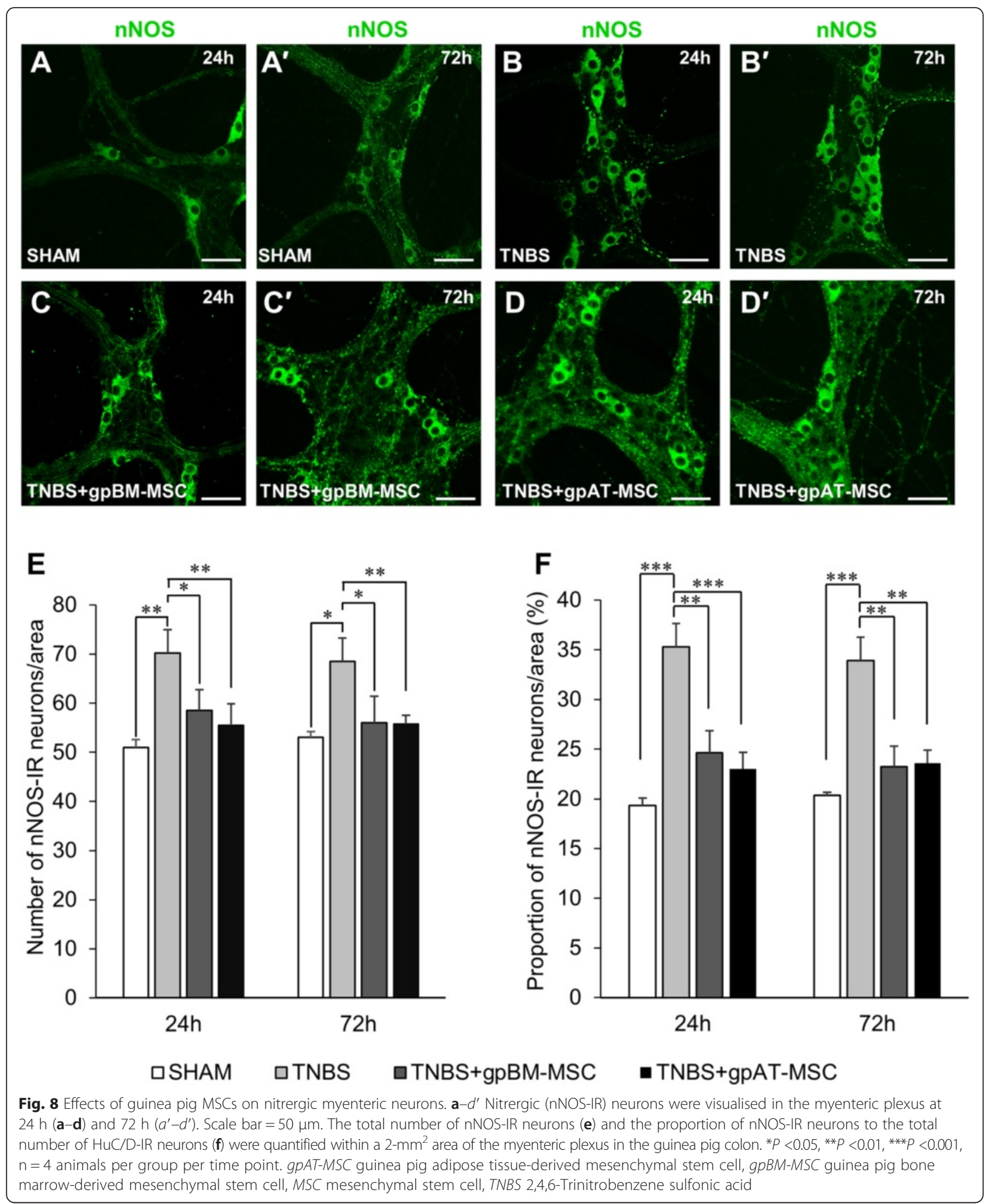

gpAT-MSC treatment. Given the absence of weight gain, this may indicate that gpAT-MSCs had a reduced overall anti-inflammatory effect.
Increased infiltration of leukocytes in the mucosa, submucosa and myenteric plexus was observed after TNBS administration which was attenuated by guinea pig MSC 


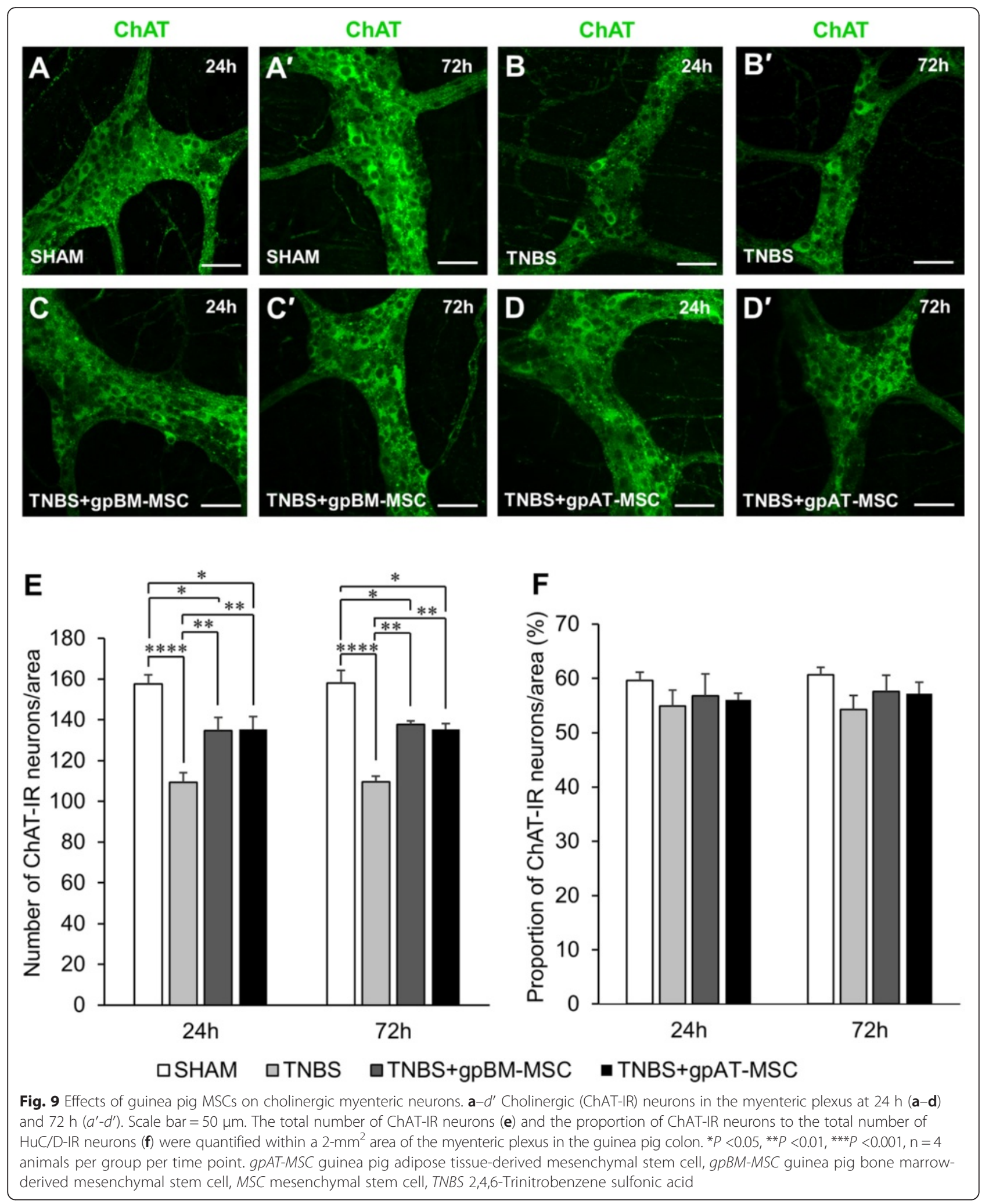

treatments. GpBM-MSCs were more effective than gpAT-MSCs in reducing the leukocyte infiltrate into the mucosa and myenteric ganglia at $24 \mathrm{~h}$ after treatment.
Differences between the immunomodulatory function of MSCs derived from bone marrow and adipose tissue have previously been observed in vitro. Human MSCs 


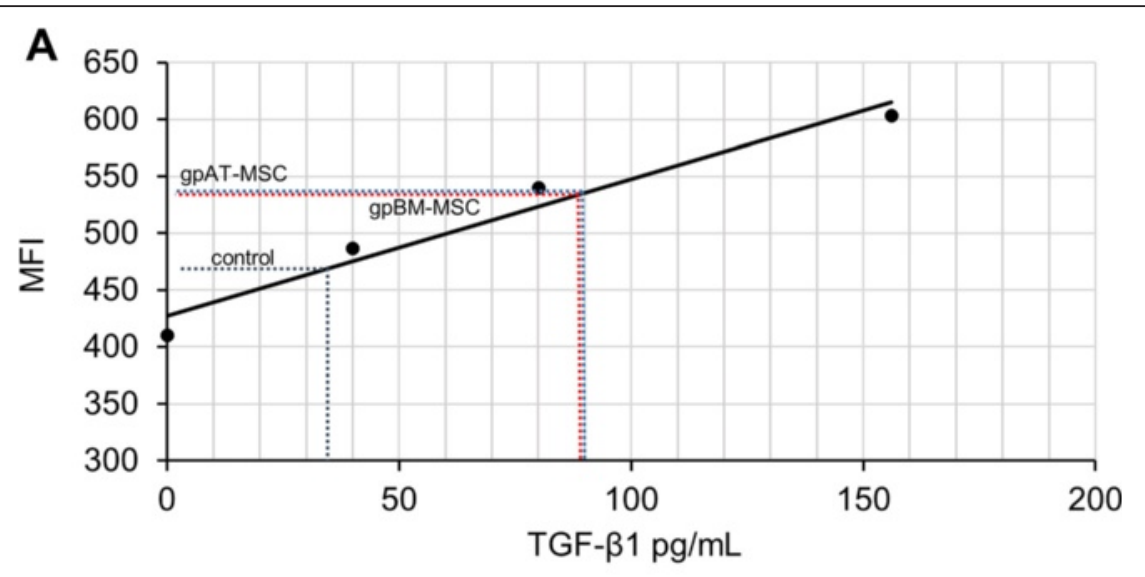

$A^{\prime}$

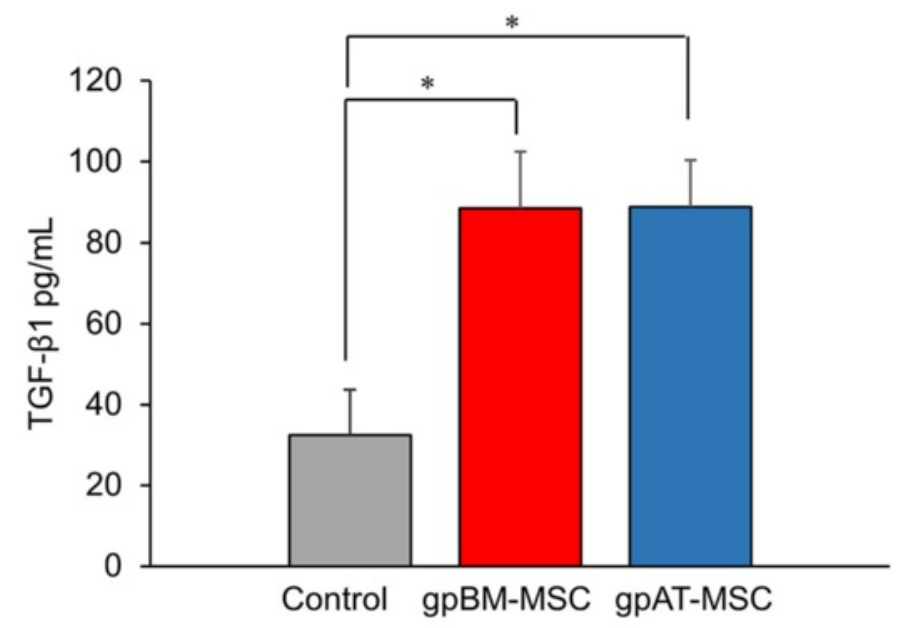

B

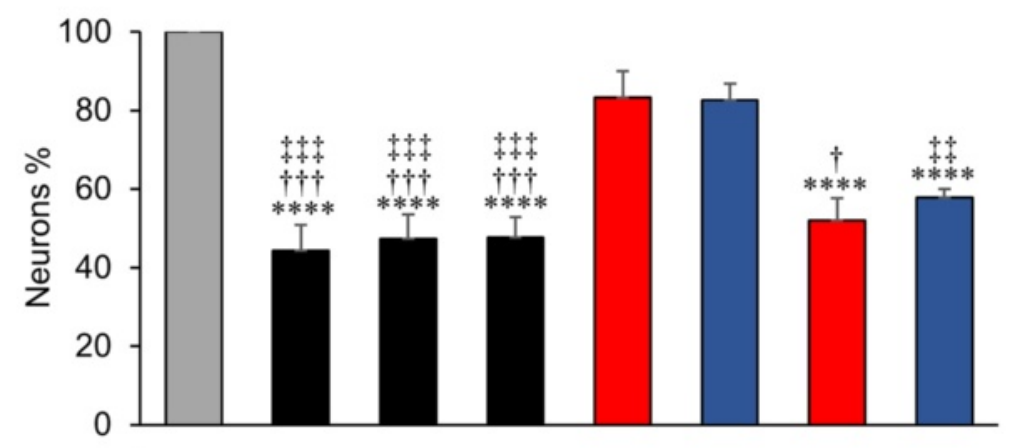

\begin{tabular}{r|c|c|c|c|c|c|c|c} 
LPS & - & + & + & + & + & + & + & + \\
\hline gpBM-MSC & - & - & - & - & + & - & + & - \\
\hline gPAT-MSC & - & - & - & - & - & + & - & + \\
\hline SB431542 & - & - & - & + & - & - & + & + \\
\hline Vehicle & - & - & + & - & + & + & - & - \\
\hline
\end{tabular}

Fig. 10 (See legend on next page.) 


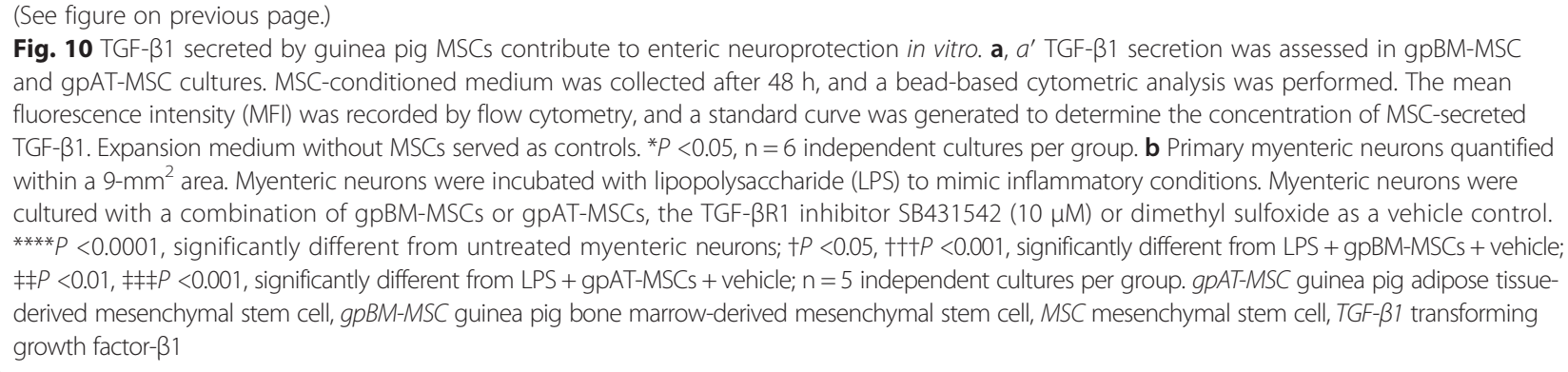

derived from bone marrow have demonstrated enhanced prevention of $\mathrm{T}$ lymphocyte proliferation and activation [79], whereas human adipose tissue-derived MSCs superiorly prevented monocyte-dendritic cell differentiation and promoted their release of anti-inflammatory interleukin-10 (IL-10) [89]. In contrast, an investigation into the ability of MSCs to suppress mixed lymphocyte reactions and mitogenesis found no differences between human MSCs from these tissue sources [90]. The results of in vitro studies are difficult to extrapolate to MSC functions in vivo; studies in animal models may give a better understanding of the immunomodulatory differences between MSCs from bone marrow and adipose tissue. An optimal tissue source of MSCs for the treatment of disease has not been established. Payne et al. [32] reported that human adipose tissue MSCs are more therapeutic than bone marrow MSCs in experimental autoimmune encephalomyelitis and this is presumably due to their greater migratory potential. Conversely, allogeneic MSCs derived from mouse bone marrow were observed to be more effective in the treatment of lung inflammation [91, 92]. Furthermore, human bone marrow MSCs were superior in preventing leukocyte infiltration into multiple organs in experimental systemic inflammation [93]. These seemingly polarised outcomes may suggest that the MSC source yielding optimal efficacy depends on the targeted pathology.

Administration of TNBS resulted in a loss of myenteric neurons consistent with other studies in animal models of experimental colitis [41-43]. No changes to the total number of neurons were observed between the time points of this study, demonstrating persistent neuronal loss after early inflammation. Treatment with guinea pig MSCs from both tissue sources equally alleviated neuronal loss. The neurochemical expressions of the two major subpopulations of myenteric neurons nNOS-IR (nitrergic) inhibitory and ChAT-IR (cholinergic) excitatory muscle motor and interneurons were investigated. Administration of TNBS increased the proportion and the total number of nitrergic neurons and decreased the total number of cholinergic neurons. Similar alterations to the neurochemical coding of enteric neurons have been previously reported in experimental colitis [49] and in tissues from patients with Crohn's disease [45, 94]. Although nNOS is traditionally constitutively expressed, previous studies have also reported increased nNOS expression in neurons of the central nervous system in response to inflammatory stimuli $[95,96]$. Mechanisms responsible for this have not yet been discerned. The proportion of cholinergic neurons in our study did not decrease and this is consistent with previous observations and may be attributed to the loss of total myenteric neurons [42]. Changes to the immunophenotype of myenteric neurons are associated with impaired coordination of muscular contractions and colonic dysmotility $[97,98]$. Our study demonstrated that both types of guinea pig MSCs inhibited the increase in the number and proportion of nitrergic neurons and ameliorated the loss of cholinergic neurons. Similar effects were previously correlated with the attenuation of inflammation-induced colonic dysmotility by human bone marrow MSCs [68].

Although gpBM-MSCs were more effective at inhibiting leukocyte infiltration to the level of the myenteric ganglia, both gpBM-MSCs and gpAT-MSCs were equally efficient at enteric neuroprotection. This suggests that MSC-mediated neuroprotection may be directly induced by the release of neurotrophic factors. Specifically, there is increasing interest in the neuroprotective value of TGF- $\beta 1$ which is secreted by MSCs $[99,100]$. Our study confirmed TGF- $\beta 1$ secretion in guinea pig MSC cultures; furthermore, levels of secretion were similar in MSCs from adipose tissue and bone marrow. In in vitro experiments, both MSCs similarly prevented myenteric neuronal loss. Furthermore, inhibition of TGF- $\beta$ R1 appeared to negate the neuroprotective ability of guinea pig MSCs. TGF- $\beta$ is widely regarded to have neuroprotective roles in the central nervous system for neurodegenerative diseases and ischemic insult $[101,102]$. The function of the TGF- $\beta 1$ isotype in neuroprotection is highlighted by Brionne et al. [103], demonstrating that neurons from TGF- $\beta 1^{-1-}$ mice had poor survival both in vivo and in culture. Furthermore, neurons from TGF- $\beta 1^{-/+}$ mice were vulnerable to excitotoxic injury. In human colon samples, analysis of mRNA from the myenteric plexus detected the presence of all TGF- $\beta$ isoforms and receptors with high levels of TGF- $\beta 1$ and TGF- $\beta$ R1 [104]. TGF- $\beta 1$ is known to be secreted by enteric glial cells critical to 
maintain neuronal survival and function [105, 106]. Recently, TGF- $\beta$ secretion by MSCs was reported to be essential to elicit a therapeutic response in patients with amyotrophic lateral sclerosis [107]. Furthermore, TGF- $\beta 1$ knockdown MSCs are ineffective for the treatment of ischemic brain injury in rats [108]. Thus, TGF- $\beta$ may play a significant role in MSC-mediated neuroprotection of the ENS.

\section{Conclusions}

Guinea pig MSCs are easily isolated from bone marrow and adipose tissue and exhibit characteristics similar to those observed in other species. Upon application into the guinea pig model of inflammation-induced neuropathy, allogeneic MSCs demonstrated immunomodulatory, trophic and neuroprotective properties. These data provide evidence of feasibility and functional efficacy of allogeneic MSC transplantation into guinea pig models. Linking the results of our in vitro and in vivo experiments, the gpAT-MSC profile of high proliferation rate, colony-forming potential and an increased number of cells with 'spindle' morphology did not provide a better therapeutic outcome. Conversely, gpBM-MSCs which were comparatively suboptimal in these in vitro traits exerted stronger anti-inflammatory efficacy in the treatment of plexitis in vivo. Both gpBM-MSCs and gpATMSCs had prominent neuroprotective effects alleviating neuronal loss and changes in neurochemical expression induced by intestinal inflammation. The neuroprotective action of MSCs appeared to be independent of their ability to prevent immune cell infiltrate. TGF- $\beta 1$ released by both types of MSCs might have contributed to the attenuation of enteric neuropathy associated with colitis.

\section{Abbreviations}

a-MEM: Alpha-minimum essential medium; CFU-f: Colony-forming unit-fibroblast; ChAT: Choline acetyltransferase; DMSO: Dimethyl sulfoxide; ENS: Enteric nervous system; gpAT-MSC: Guinea pig adipose tissue-derived mesenchymal stem cell; gpBM-MSC: Guinea pig bone marrow-derived mesenchymal stem cell; IBD: Inflammatory bowel disease; IR: Immunoreactive; LPS: Lipopolysaccharide; MAP-2: Microtubule-associated protein-2; MSC: Mesenchymal stem cell; nNOS: Neuronal nitric oxide synthase; OCT: Optimal cutting temperature; PBS: Phosphate-buffered saline; PDL: Population doubling level; RGB: Red, green, and blue; TGF- $\beta 1$ : Transforming growth factor- $\beta 1$; TGF- $\beta$ R1: Transforming growth factor- $\beta$ receptor 1; TNBS: 2,4,6-Trinitrobenzene sulfonic acid.

\section{Competing interests}

The authors declare that they do not have any competing interests.

\section{Authors' contributions}

RS wrote the manuscript and performed in vitro experimental design, cell culture and characterisation, animal work, immunohistochemical studies, flow cytometry and statistical analysis. AR contributed to writing of the manuscript, animal work, immunohistochemical studies and histology. SM contributed to animal work and critical revision of the manuscript. RB critically revised the manuscript for important intellectual content. SS performed fluorescenceactivated cell sorting analysis, contributed to writing of the manuscript and helped to supervise the study and obtain funding. KN designed the project, contributed to writing of the manuscript and helped to supervise the study and obtain funding. All authors read and approved the final manuscript.

\section{Acknowledgements}

This work was supported by a Victoria University Research Development grant.

\section{Author details}

${ }^{1}$ Centre for Chronic Disease, College of Health and Biomedicine, Western Centre for Health, Research and Education, Sunshine Hospital, 176 Furlong road, Melbourne 3021Victoria, Australia. ${ }^{2}$ Department of Anatomy and Developmental Biology, Monash University, 19 Innovation Walk, Clayton 3800Victoria, Australia.

Received: 3 August 2015 Revised: 12 November 2015 Accepted: 2 December 2015 Published online: 30 December 2015

\section{References}

1. Molodecky NA, Soon IS, Rabi DM, Ghali WA, Ferris M, Chernoff G, et al. Increasing incidence and prevalence of the inflammatory bowel diseases with time, based on systematic review. Gastroenterology. 2012;142:46-54.

2. Strober W, Fuss I, Mannon P. The fundamental basis of inflammatory bowel disease. J Clin Invest. 2007;117:514-21.

3. Pithadia $A B$, Jain $\mathrm{S}$. Treatment of inflammatory bowel disease (IBD). Pharmacol Rep. 2011;63:629-42.

4. Vester-Andersen MK, Prosberg MV, Jess T, Andersson M, Bengtsson BG, Blixt $T$, et al. Disease course and surgery rates in inflammatory bowel disease: a population-based, 7-year follow-up study in the era of immunomodulating therapy. Am J Gastroenterol. 2014;109:705-14.

5. Isaacs $\mathrm{K}$, Herfarth $\mathrm{H}$. Role of probiotic therapy in IBD. Inflamm Bowel Dis. 2008;14:1597-605

6. Singh UP, Singh NP, Singh B, Mishra MK, Nagarkatti M, Nagarkatti PS, et al. Stem cells as potential therapeutic targets for inflammatory bowel disease. Front Biosci (Schol Ed). 2010;2:993-1008.

7. Wang S, Qu X, Zhao RC. Clinical applications of mesenchymal stem cells. J Hematol Oncol. 2012;5:19.

8. Wei X, Yang X, Han ZP, Qu FF, Shao L, Shi YF. Mesenchymal stem cells: a new trend for cell therapy. Acta Pharmacol Sin. 2013;34:747-54.

9. Dominici M, Le Blanc K, Mueller I, Slaper-Cortenbach I, Marini F, Krause D, et al. Minimal criteria for defining multipotent mesenchymal stromal cells. The International Society for Cellular Therapy position statement. Cytotherapy. 2006:8:315-7.

10. Caplan Al. Mesenchymal stem cells. J Orthop Res. 1991;9:641-50.

11. Mosna F, Sensebe L, Krampera M. Human bone marrow and adipose tissue mesenchymal stem cells: a user's guide. Stem Cells Dev. 2010;19:1449-70.

12. Zuk PA, Zhu M, Ashjian P, De Ugarte DA, Huang Jl, Mizuno H, et al. Human adipose tissue is a source of multipotent stem cells. Mol Biol Cell. 2002:13:4279-95.

13. Chamberlain G, Fox J, Ashton B, Middleton J. Concise review: mesenchymal stem cells: their phenotype, differentiation capacity, immunological features, and potential for homing. Stem Cells. 2007;25:2739-49.

14. Ankrum JA, Ong JF, Karp JM. Mesenchymal stem cells: immune evasive, not immune privileged. Nat Biotechnol. 2014;32:252-60.

15. Li J, Ezzelarab MB, Cooper DK. Do mesenchymal stem cells function across species barriers? Relevance for xenotransplantation. Xenotransplantation. 2012;19:273-85.

16. Karp JM, Leng Teo GS. Mesenchymal stem cell homing: the devil is in the details. Cell Stem Cell. 2009:4:206-16.

17. Ma S, Xie N, Li W, Yuan B, Shi Y, Wang Y. Immunobiology of mesenchymal stem cells. Cell Death Differ. 2013;21:216-25.

18. Chen L, Tredget EE, Wu PY, Wu Y. Paracrine factors of mesenchymal stem cells recruit macrophages and endothelial lineage cells and enhance wound healing. PLOS One. 2008:3, e1886.

19. Sémont A, Demarquay C, Bessout R, Durand C, Benderitter M, Mathieu N. Mesenchymal stem cell therapy stimulates endogenous host progenitor cells to improve colonic epithelial regeneration. PLoS One. 2013;8, e70170.

20. Wu Y, Chen L, Scott PG, Tredget EE. Mesenchymal stem cells enhance wound healing through differentiation and angiogenesis. Stem Cells. 2007:25:2648-59.

21. Forbes GM, Sturm MJ, Leong RW, Sparrow MP, Segarajasingam D, Cummins $A G$, et al. A phase 2 study of allogeneic mesenchymal stromal cells for luminal Crohn's disease refractory to biologic therapy. Clin Gastroenterol Hepatol. 2014;12:64-71.

22. Duijvestein $M$, Vos ACW, Roelofs $H$, Wildenberg ME, Wendrich $B B$, Verspaget $\mathrm{HW}$, et al. Autologous bone marrow-derived mesenchymal stromal cell 
treatment for refractory luminal Crohn's disease: results of a phase I study. Gut. 2010;59:1662-9.

23. Ciccocioppo R, Bernardo ME, Sgarella A, Maccario R, Avanzini MA, Ubezio C, et al. Autologous bone marrow-derived mesenchymal stromal cells in the treatment of fistulising Crohn's disease. Gut. 2011;60:788-98.

24. Bouchez G, Sensebé L, Vourc'h P, Garreau L, Bodard S, Rico A, et al. Partial recovery of dopaminergic pathway after graft of adult mesenchymal stem cells in a rat model of Parkinson's disease. Neurochem Int. 2008;52:1332-42.

25. Han X, Gao W, Chen L, Yang H, Shi Q. Promotion of neurological recovery in rat spinal hemisection injury by collagen scaffold loaded with mesenchymal stem cells. Bone Joint J. 2014;96 suppl 11:246.

26. Harting MT, Jimenez F, Xue H, Fischer UM, Baumgartner J, Dash PK, et al. Intravenous mesenchymal stem cell therapy for traumatic brain injury. J Neurosurg. 2009;1 10:1189-97.

27. Ikegame Y, Yamashita K, Hayashi S, Mizuno H, Tawada M, You F, et al. Comparison of mesenchymal stem cells from adipose tissue and bone marrow for ischemic stroke therapy. Cytotherapy. 2011;13:675-85.

28. Karussis D, Kassis I, Kurkalli BGS, Slavin S. Immunomodulation and neuroprotection with mesenchymal bone marrow stem cells (MSCs): a proposed treatment for multiple sclerosis and other neuroimmunological/neurodegenerative diseases. J Neurol Sci. 2008:265:131-5.

29. Lanza C, Morando S, Voci A, Canesi L, Principato MC, Serpero LD, et al. Neuroprotective mesenchymal stem cells are endowed with a potent antioxidant effect in vivo. J Neurochem. 2009;110:1674-84.

30. Lin Y-T, Chern Y, Shen C-K, Wen H-L, Chang Y-C, Li H, et al. Human mesenchymal stem cells prolong survival and ameliorate motor deficit through trophic support in Huntington's disease mouse models. PLoS One. 2011;6, e22924.

31. Matthes SM, Reimers K, Janssen I, Liebsch C, Kocsis JD, Vogt PM, et al. Intravenous transplantation of mesenchymal stromal cells to enhance peripheral nerve regeneration. Biomed Res Int. 2013;2013:573169.

32. Payne NL, Sun G, McDonald C, Layton D, Moussa L, Emerson-Webber A, et al. Distinct immunomodulatory and migratory mechanisms underpin the therapeutic potential of human mesenchymal stem cells in autoimmune demyelination. Cell Transplant. 2013;22:1409-25.

33. Vercelli A, Mereuta O, Garbossa D, Muraca G, Mareschi K, Rustichelli D, et al. Human mesenchymal stem cell transplantation extends survival, improves motor performance and decreases neuroinflammation in mouse model of amyotrophic lateral sclerosis. Neurobiol Dis. 2008:31:395-405.

34. Díez-Tejedor E, Gutiérrez-Fernández M, Martínez-Sánchez P, RodríguezFrutos B, Ruiz-Ares G, Lara ML, et al. Reparative therapy for acute ischemic stroke with allogeneic mesenchymal stem cells from adipose tissue: a safety assessment: a phase II randomized, double-blind, placebo-controlled, singlecenter, pilot clinical trial. J Stroke Cerebrovasc Dis. 2014;23:2694-700.

35. Thomsen GM, Gowing G, Svendsen S, Svendsen CN. The past, present and future of stem cell clinical trials for ALS. Exp Neurol. 2014;262(Part B):127-37.

36. De Giorgio R, Barbara G, Furness JB, Tonini M. Novel therapeutic targets for enteric nervous system disorders. Trends Pharmacol Sci. 2007;28:473-81.

37. Lomax AE, Fernández E, Sharkey KA. Plasticity of the enteric nervous system during intestinal inflammation. Neurogastroenterol Motil. 2005;17:4-15.

38. Lakhan SE, Kirchgessner A. Neuroinflammation in inflammatory bowel disease. J Neuroinflammation. 2010;7:37.

39. Hansen MB. The enteric nervous system III: a target for pharmacological treatment. Pharmacol Toxicol. 2003;93:1-13.

40. Furness JB. The enteric nervous system and neurogastroenterology. Nat Rev Gastroenterol Hepatol. 2012;9:286-94.

41. Boyer L, Ghoreishi M, Templeman V, Vallance BA, Buchan AM, Jevon G, et al. Myenteric plexus injury and apoptosis in experimental colitis. Auton Neurosci. 2005;117:41-53.

42. Linden D, Couvrette J, Ciolino A, McQuoid C, Blaszyk H, Sharkey K, et al. Indiscriminate loss of myenteric neurones in the TNBS-inflamed guinea-pig distal colon. Neurogastroenterol Motil. 2005;17:751-60.

43. Nurgali K, Qu Z, Hunne B, Thacker M, Pontell L, Furness JB. Morphological and functional changes in guinea-pig neurons projecting to the ileal mucosa at early stages after inflammatory damage. J Physiol. 2011;589:325-39.

44. Sarnelli G, De Giorgio R, Gentile F, Cali G, Grandone I, Rocco A, et al. Myenteric neuronal loss in rats with experimental colitis: role of tissue transglutaminase-induced apoptosis. Dig Liver Dis. 2009;41:185-93.
45. Boyer L, Sidpra D, Jevon G, Buchan AM, Jacobson K. Differential responses of VIPergic and nitrergic neurons in paediatric patients with Crohn's disease. Auton Neurosci. 2007;134:106-14.

46. de Fontgalland D, Brookes SJ, Gibbins I, Sia TC, Wattchow DA. The neurochemical changes in the innervation of human colonic mesenteric and submucosal blood vessels in Ulcerative colitis and Crohn's disease. Neurogastroenterol Motil. 2014;26:731-44.

47. Neunlist M, Aubert P, Toquet C, Oreshkova T, Barouk J, Lehur P, et al. Changes in chemical coding of myenteric neurones in ulcerative colitis. Gut. 2003;52:84-90.

48. Schneider J, Jehle EC, Starlinger MJ, Neunlist M, Michel K, Hoppe S, et al. Neurotransmitter coding of enteric neurones in the submucous plexus is changed in non-inflamed rectum of patients with Crohn's disease. Neurogastroenterol Motil. 2001;13:255-64.

49. Winston JH, Li Q, Sarna SK. Paradoxical regulation of ChAT and nNOS expression in animal models of Crohn's colitis and ulcerative colitis. Am J Physiol Gastrointest Liver Physiol. 2013;305:G295-302.

50. Bressenot A, Chevaux JB, Williet N, Oussalah A, Germain A, Gauchotte G, et al. Submucosal plexitis as a predictor of postoperative surgical recurrence in Crohn's disease. Inflamm Bowel Dis. 2013;19:1654-61.

51. Ferrante M, de Hertogh G, Hlavaty T, D'Haens G, Penninckx F, D'Hoore A, et al. The value of myenteric plexitis to predict early postoperative Crohn's disease recurrence. Gastroenterology. 2006;130:1595-606.

52. Sokol H, Polin V, Lavergne-Slove A, Panis $Y$, Treton X, Dray X, et al. Plexitis as a predictive factor of early postoperative clinical recurrence in Crohn's disease. Gut. 2009;58:1218-25.

53. Furness J. The Enteric Nervous System. Oxford: Blackwell; 2006.

54. Nurgali K. Plasticity and ambiguity of the electrophysiological phenotypes of enteric neurons. Neurogastroenterol Motil. 2009;21:903-13.

55. Galligan J. Ligand-gated ion channels in the enteric nervous system. Neurogastroenterol Motil. 2002;14:611-23.

56. Cross RW, Fenton KA, Geisbert JB, Mire CE, Geisbert TW. Modeling the disease course of Zaire ebolavirus infection in the outbred guinea pig. J Infect Dis. 2015;212 Suppl 2:S305-15.

57. Padilla-Carlin DJ, McMurray DN, Hickey AJ. The guinea pig as a model of infectious diseases. Comp Med. 2008;58:324.

58. Domínguez-Fandos D, Valdés C, Ferrer E, Puig-Pey R, Blanco I, Tura-Ceide O, et al. Sildenafil in a cigarette smoke-induced model of COPD in the guinea pig. Eur Respir J. 2015:46:346-54.

59. Pettingill LN, Wise AK, Geaney MS, Shepherd RK. Enhanced auditory neuron survival following cell-based BDNF treatment in the deaf guinea pig. PLoS One. 2011;6, e18733.

60. Soo PS, Hiscock J, Botting KJ, Roberts CT, Davey AK, Morrison JL. Maternal undernutrition reduces P-glycoprotein in guinea pig placenta and developing brain in late gestation. Reprod Toxicol. 2012;33:374-81.

61. Liu T, Takimoto E, Dimaano VL, DeMazumder D, Kettlewell S, Smith G, et al. Inhibiting mitochondrial $\mathrm{Na}+/ \mathrm{Ca} 2+$ exchange prevents sudden death in a guinea pig model of heart failure. Circ Res. 2014;115:44-54.

62. Nurgali K, Nguyen TV, Matsuyama H, Thacker M, Robbins HL, Furness JB. Phenotypic changes of morphologically identified guinea-pig myenteric neurons following intestinal inflammation. J Physiol. 2007;583:593-609.

63. Nurgali K, Nguyen TV, Thacker M, Pontell L, Furness JB. Slow synaptic transmission in myenteric AH neurons from the inflamed guinea pig ileum. Am J Physiol Gastrointest Liver Physiol. 2009;297:G582-G93.

64. Linden DR. Enhanced excitability of guinea pig ileum myenteric AH neurons during and following recovery from chemical colitis. Neurosci Lett. 2013; 545:91-5.

65. Lomax AE, O'Hara JR, Hyland NP, Mawe GM, Sharkey KA. Persistent alterations to enteric neural signaling in the guinea pig colon following the resolution of colitis. Am J Physiol Gastrointest Liver Physiol. 2007;292:G482-G91.

66. Sato M, Uchida K, Nakajima H, Miyazaki T, Guerrero AR, Watanabe S, et al. Direct transplantation of mesenchymal stem cells into the knee joints of Hartley strain guinea pigs with spontaneous osteoarthritis. Arthritis Res Ther. 2012;14:R31.

67. Duan HG, Ji F, Zheng CQ, Wang CH, Li J. Human umbilical cord mesenchymal stem cells alleviate nasal mucosa radiation damage in a guinea pig model. J Cell Biochem. 2015;116:331-8.

68. Robinson AM, Sakkal S, Park A, Jovanovska V, Payne N, Carbone SE, et al. Mesenchymal stem cells and conditioned medium avert enteric neuropathy and colon dysfunction in quinea pig TNBS-induced colitis. Am J Physiol Gastrointest Liver Physiol. 2014;307:G1115-G29. 
69. Payne NL, Sun G, McDonald C, Moussa L, Emerson-Webber A, Loisel-Meyer $S$, et al. Human adipose-derived mesenchymal stem cells engineered to secrete IL-10 inhibit APC function and limit CNS autoimmunity. Brain Behav Immun. 2013;30:103-14.

70. Cristofalo VJ, Allen RG, Pignolo RJ, Martin BG, Beck JC. Relationship between donor age and the replicative lifespan of human cells in culture: a reevaluation. Proc Natl Acad Sci U S A. 1998;95:10614-9.

71. Pontell L, Castelucci P, Bagyánszki M, Jovic T, Thacker M, Nurgali K, et al. Structural changes in the epithelium of the small intestine and immune cell infiltration of enteric ganglia following acute mucosal damage and local inflammation. Virchows Arch. 2009;455:55-65.

72. Grundmann D, Klotz M, Rabe H, Glanemann M, Schäfer K-H. Isolation of high-purity myenteric plexus from adult human and mouse gastrointestinal tract. Sci Rep. 2015;9226.

73. Bourin $\mathrm{P}$, Bunnell BA, Casteilla L, Dominici M, Katz AJ, March KL, et al. Stromal cells from the adipose tissue-derived stromal vascular fraction and culture expanded adipose tissue-derived stromal/stem cells: a joint statement of the International Federation for Adipose Therapeutics and Science (IFATS) and the International Society for Cellular Therapy (ISCT). Cytotherapy. 2013;15:641-8.

74. Furness J. Types of neurons in the enteric nervous system. J Auton Nerv Syst. 2000;81:87-96.

75. Lasco TM, Gonzalez-Juarrero M, Saalmüller A, Lunney JK. Cross-reaction of anti-human CD monoclonal antibodies on guinea pig cells: A summary of the guinea pig section of the HLDA8 animal homologues data. Vet Immunol Immunopathol. 2007;119:131-6.

76. Li Q, Qi L-J, Guo Z-K, Li H, Zuo H-B, Li N-N. CD73+ adipose-derived mesenchymal stem cells possess higher potential to differentiate into cardiomyocytes in vitro. J Mol Histol. 2013;44:411-22.

77. Frölich K, Scherzed A, Mlynski R, Technau A, Hagen R, Kleinsasser N, et al. Multipotent stromal cells for autologous cell therapy approaches in the guinea pig model. J Otorhinolaryngol Relat Spec. 2010;73:9-16.

78. Dmitrieva RI, Minullina IR, Bilibina AA, Tarasova OV, Anisimov SV, Zaritskey AY. Bone marrow-and subcutaneous adipose tissue-derived mesenchymal stem cells: differences and similarities. Cell Cycle. 2012;11:377-83.

79. Zhu X, Shi W, Tai W, Liu F. The comparition of biological characteristics and multilineage differentiation of bone marrow and adipose derived Mesenchymal stem cells. Cell Tissue Res. 2012;350:277-87.

80. Schellenberg A, Stiehl T, Horn P, Joussen S, Pallua N, Ho AD, et al. Population dynamics of mesenchymal stromal cells during culture expansion. Cytotherapy. 2012;14:401-11.

81. Ayatollahi M, Salmani MK, Geramizadeh B, Tabei SZ, Soleimani M, Sanati MH. Conditions to improve expansion of human mesenchymal stem cells based on rat samples. World J Stem Cells. 2012:4:1-8.

82. Le Blanc K. Mesenchymal stromal cells: tissue repair and immune modulation. Cytotherapy. 2006;8:559-61.

83. Javazon EH, Beggs KJ, Flake AW. Mesenchymal stem cells: paradoxes of passaging. Exp Hematol. 2004:32:414-25.

84. Gothard D, Dawson J, Oreffo R. Assessing the potential of colony morphology for dissecting the CFU-F population from human bone marrow stromal cells. Cell Tissue Res. 2013;352:237-47.

85. Taghi GM, Maryam GK, Taghi L, Leili H, Leyla M. Characterization of in vitro cultured bone marrow and adipose tissue-derived mesenchymal stem cells and their ability to express neurotrophic factors. Cell Biol Int. 2012;36:1239-49.

86. Wirtz S, Neufert C, Weigmann B, Neurath MF. Chemically induced mouse models of intestinal inflammation. Nat Protoc. 2007:2:541-6.

87. Linden DR, Sharkey KA, Mawe GM. Enhanced excitability of myenteric AH neurones in the inflamed guinea-pig distal colon. J Physiol. 2003;547:589-601.

88. Haskó G, Linden J, Cronstein B, Pacher P. Adenosine receptors: therapeutic aspects for inflammatory and immune diseases. Nat Rev Drug Discov. 2008;7:759-70

89. Ivanova-Todorova E, Bochev I, Mourdjeva M, Dimitrov R, Bukarev D, Kyurkchiev $\mathrm{S}$, et al. Adipose tissue-derived mesenchymal stem cells are more potent suppressors of dendritic cells differentiation compared to bone marrowderived mesenchymal stem cells. Immunol Lett. 2009;126:37-42.

90. Puissant B, Barreau C, Bourin P, Clavel C, Corre J, Bousquet C, et al Immunomodulatory effect of human adipose tissue-derived adult stem cells: comparison with bone marrow mesenchymal stem cells. Br J Haematol. 2005;129:118-29.
91. Antunes M, Branco V, Diaz B, Morales M, Xisto D, Rocco P, et al. Mesenchymal stem cells derived from bone marrow present better effects on lung inflammation and remodeling compared with other sources in experimental asthma. Am J Respir Crit Care Med. 2014;189:A5291.

92. Antunes MA, Abreu SC, Cruz FF, Teixeira AC, Lopes-Pacheco M, Bandeira E, et al. Effects of different mesenchymal stromal cell sources and delivery routes in experimental emphysema. Respir Res. 2014;15:118.

93. Elman JS, Li M, Wang F, Gimble JM, Parekkadan B. A comparison of adipose and bone marrow-derived mesenchymal stromal cell secreted factors in the treatment of systemic inflammation. J Inflamm (Lond). 2014;11:1.

94. Belai A, Boulos PB, Robson T, Burnstock G. Neurochemical coding in the small intestine of patients with Crohn's disease. Gut. 1997;40:767-74.

95. Di Girolamo G, Farina M, Riberio ML, Ogando D, Aisemberg J. de los Santos $A R$, et al. Effects of cyclooxygenase inhibitor pretreatment on nitric oxide production, nNOS and iNOS expression in rat cerebellum. Br J Pharmacol. 2003;139:1164-70.

96. Wu J, Lin Q, Lu Y, Willis WD, Westlund KN. Changes in nitric oxide synthase isoforms in the spinal cord of rat following induction of chronic arthritis. Exp Brain Res. 1998;118:457-65.

97. Suply E, de Vries P, Soret R, Cossais F, Neunlist M. Butyrate enemas enhance both cholinergic and nitrergic phenotype of myenteric neurons and neuromuscular transmission in newborn rat colon. Am J Physiol Gastrointest Liver Physiol. 2012;302:G1373-80.

98. Wattchow D, Brookes S, Murphy E, Carbone S, De Fontgalland D, Costa M. Regional variation in the neurochemical coding of the myenteric plexus of the human colon and changes in patients with slow transit constipation. Neurogastroenterol Motil. 2008;20:1298-305.

99. Dobolyi A, Vincze C, Pal G, Lovas G. The neuroprotective functions of transforming growth factor Beta proteins. Int J Mol Sci. 2012;13:8219-58.

100. da Silva ML, Fontes AM, Covas DT, Caplan Al. Mechanisms involved in the therapeutic properties of mesenchymal stem cells. Cytokine Growth Factor Rev. 2009;20:419-27.

101. Caraci F, Spampinato S, Sortino MA, Bosco P, Battaglia G, Bruno V, et al. Dysfunction of TGF- $\beta 1$ signaling in Alzheimer's disease: perspectives for neuroprotection. Cell Tissue Res. 2012;347:291-301.

102. Liu FF, Liu CY, Li XP, Zheng SZ, Li QQ, Liu Q, et al. Neuroprotective effects of SMADs in a rat model of cerebral ischemia/reperfusion. Neural Regen Res. 2015;10:438

103. Brionne TC, Tesseur I, Masliah E, Wyss-Coray T. Loss of TGF- $\beta 1$ leads to increased neuronal cell death and microgliosis in mouse brain. Neuron. 2003:40:1133-45.

104. Hagl C, Schäfer KH, Hellwig I, Barrenschee M, Harde J, Holtmann M, et al. Expression and function of the transforming growth factor-b system in the human and rat enteric nervous system. Neurogastroenterol Motil. 2013;25: $601-\mathrm{e} 464$.

105. Neunlist $M$, Aubert $P$, Bonnaud $S$, Van Landeghem L, Coron E, Wedel T, et al. Enteric glia inhibit intestinal epithelial cell proliferation partly through a TGF-beta1-dependent pathway. Am J Physiol Gastrointest Liver Physiol. 2007;292:G231-41.

106. De Giorgio R, Giancola F, Boschetti E, Abdo H, Lardeux B, Neunlist M. Enteric glia and neuroprotection: basic and clinical aspects. Am J Physiol Gastrointest Liver Physiol. 2012;303:G887-G93.

107. Kim HY, Kim H, Oh KW, Oh SI, Koh SH, Baik W, et al. Biological markers of mesenchymal stromal cells as predictors of response to autologous stem cell transplantation in patients with amyotrophic lateral sclerosis: an investigator-initiated trial and in vivo study. Stem Cells. 2014;32:2724-31.

108. Yoo SW, Chang DY, Lee HS, Kim GH, Park JS, Ryu BY, et al. Immune following suppression mesenchymal stem cell transplantation in the ischemic brain is mediated by TGF- $\beta$. Neurobiol Dis. 2013;58:249-57. 